\title{
SEASONAL VARIATION OF SURFACE ENERGY BALANCE OF A CENTRAL BRAZIL CITY
}

\author{
variação sazonal do balanço de energia em cidade localizada na região central do Brasil
}

\author{
Ivan Julio Apolonio Callejas * \\ Marta Cristina de Jesus Albuquerque Nogueira ** \\ Marcelo Sacardi Biudes *** \\ Luciane Cleonice Durante ****
}

\begin{abstract}
Resumo
A concentração e o crescimento populacional experimentado pela cidade de Cuiabá desde 70 tem favorecido o rápido processo de mudanças de cobertura do solo no clima tropical local, principalmente por causa da substituição de áreas naturais por edifícios e superfícies impermeáveis. Com base neste cenário, esta pesquisa teve como objetivo avaliar as trocas entre a superfície e atmosfera de um sítio urbano localizado nas proximidades da região central da cidade de Cuiabá. Em geral, as frações de particionamento de fluxo de calor antropogênico $(\mathrm{QF})$, de calor armazenado dentro do dossel urbano $(\Delta \mathrm{Qs})$, dos fluxos de calor latente $(\mathrm{QE})$ e dos fluxos de calor sensível (QH) corresponderam a 3, 26, 28 e 46\% e 3, 23, 31 e 46\% da energia disponível no ambiente $\left(\mathrm{Q}^{*}+\mathrm{QF}\right)$, na estação seca e úmida, respectivamente. Estas frações do balanço de energia foram semelhantes às observadas na cidade de Miami, mas diferiram em termos do momento do pico e a intensidade. Os índices médios diurnos da razão de Bowen ( $\beta$ ) nas estações seca e chuvosa foram 1,67 e 1,55, apresentando relação direta com a área da cobertura vegetal. Os fluxos de calor sensível e latente se correlacionaram positivamente respectivamente com a superfície impermeável e vegetada.
\end{abstract}

Palavras-chave: Fluxos de energia; Razão de Bowen; Dossel urbano.

\begin{abstract}
This intense growth and populational concentration experienced by Cuiabá City since the 70's has favored to the rapid process of land cover changes on local tropical climate mainly because the replacement of preserved natural areas by building and impervious surfaces. Based on this scenario, this research aimed to evaluate the surface-atmosphere exchanges of an urban site located near downtown of Cuiaba City. In general, the fraction of flux partitioning of anthropogenic heat flux $(\mathrm{QF})$, heat stored inside the urban canopy $(\Delta \mathrm{Qs})$, latent heat fluxes $(\mathrm{QE})$ and sensible heat fluxes $(\mathrm{QH})$ corresponded to 3, 26, 28 and $46 \%$ and 3 , 23,31 and $46 \%$ of energy available in the environment $\left(\mathrm{Q}^{*}+\mathrm{QF}\right)$, in the dry and wet season respectively. These fractions of the energy balance were similar to those observed in Miami City, but differ in terms of the timing of the peak and the intensity. The average diurnal Bowen ratios $(\beta)$ in the dry and wet seasons were 1.67 and 1.55 and showed directed relation with decreasing vegetation cover area. Sensible and latent heat fluxes were positively correlated with impervious surface and vegetated area.
\end{abstract}

Key words: Urban energy fluxes; Bowen ratio; Urban canopy.

\section{Resumen}

El crecimiento de la concentración y de la población que sufre la ciudad de Cuiabá desde el 70 ha favorecido el rápido proceso de cambio de cobertura del suelo en el clima tropical locales, principalmente debido a la sustitución de los espacios naturales por edificios y superficies impermeables. En este contexto, este estudio tuvo como objetivo evaluar el balance de energía en el entorno urbano situado en el centro de la ciudad de Cuiabá. El flujo de calor antropogénico $(\mathrm{QF})$, el calor almacenado en el dosel urbana $(\Delta \mathrm{Q})$, el calor latente (QE) y el calor sensible (QH) correspondió en la estación seca y húmeda a 3, 26, 28 y 46\%, y el 3, 23, 31 y $46 \%$ de la energía disponible en el medio $\left(Q^{*}+Q F\right)$, respectivamente. Estas fracciones de balance de energía fueron similares a los observados en la ciudad de Miami, pero difieren en cuanto a la sincronización del pico y la intensidad. La relación de Bowen $(\beta)$ en la estación seca y húmeda fueron 1,67 y 1,55, están directamente relacionados con el área de la cubierta vegetal. Los flujos de calor sensible y latente se correlacionaron positivamente, respectivamente, con superficie impermeable y vegetación.

Palabras claves: Flujos de energía; Razón del Bowen; Canopy urbana.-

(*) Lecturer Federal University of Mato Grosso (Universidade Federal do Mato Grosso) - R. Fernando Corrêa da Costa, 2367, CEP: 78060-900, Cuiabá (MT) Brasil. Tel: (+55 65)36158774-ivancallejas1973@gmail.com

(**) Lecturer Federal University of Mato Grosso (Universidade Federal do Mato Grosso) - R. Fernando Corrêa da Costa, 2367, CEP: 78060-900, Cuiabá (MT) Brasil. Tel: (+55 65) 36158774 - mcjanp@gmail.com

(***) Lecturer Federal University of Mato Grosso (Universidade Federal do Mato Grosso) - R. Fernando Corrêa da Costa, 2367, CEP: 78060-900, Cuiabá (MT) Brasil. Tel: (+55 65) 36158774 - marcelo@fisica.ufmt.br

(****) Lecturer Federal University of Mato Grosso (Universidade Federal do Mato Grosso) - R. Fernando Corrêa da Costa, 2367, CEP: 78060-900, Cuiabá (MT) Brasil. Tel: (+55 65) 36158774 - luciane.durante@hotmail.com 


\section{INTRODUCTION}

The effects of anthropogenic activities in climate of the cities have been observed to understand how minimize the effects of urbanization in climate change. Systematic studies to diagnose the effects of urbanization in the climate of the cities have been conducted since the first decades of the 19th century. In Brazil, the studies regarding urban climate has started by the seventies, after the publication of Monteiro (1976), who elaborated a theoretical model for the investigation of the climate behavior of the cities. According to the author,

the city generates its own climate (urban climate), as a result of the interference of all the factors that deal with the urban boundary layer and act in the direction of changing the climate at local scale. Its straightforward effects are realized by the population through demonstrations related to thermal comfort, air quality, storm impacts and other manifestations capable of disorganizing the life of the city and deteriorating the quality of life of its inhabitants (MONTEIRO, 1976).

For the author, "the urban climate is a system that comprises the climate in a given boundary and its urbanization". In his model, the author developed an analysis methodology that considers the urban climate as a system - Urban Climate System (Sistema Clima Urbano in Portuguese SCU) - composed by subsystems that are articulated along with climatic perception channels. On the other hand, Oke (1987) defined urban climate as a result of the changes caused by the process of urbanization of the land surface and by the interference of this urbanization in the characteristics of the atmosphere in a given area.

The urbanization of the cities, with its rapid population growth, results in the land surface change and in its atmosphere. These changes are caused, extensively, by anthropogenic activities, such as, pollutants emissions, which affect the radiation transfer and add condensation nuclei to the air; intense industrial activities; suppression of native forests; population density increase; and density and shape of the buildings. These modifications create a roughened surface that determines air circulation, heat and water vapor transport inside the urban canopy. Other urban landscape modifications like the use of paving materials change soil permeability, causing high heat stored and floods (MONTEIRO e MENDONÇA, 2003; ROTH, 2007).

The focus of the current study in urban climate concentrates, essentially, in themes such as the energy balance, atmosphere contamination and air quality (atmospheric pollution and its effects in health), thermal comfort (heat islands configuration) and concentrated storm impacts (which cause frequent floods).

From the point of view of energy balance, Oke (1987) stated that the climate is a physical and thermodynamic process that connects the surface and the boundary layer. Through this process, temperature flows and air humidity are determined, as well as superficial heat fluxes (conduction exchange between the surface and the underlying substrate), that contribute significantly to the average potential temperature profile within the atmospheric boundary layer. In relation to the urban surface, the intensity of turbulences are greater than in rural areas, mainly due to the nature of the existing obstacles in the environment that indicates that heat flows and humidity depend more on the nature of the existing turbulence within the atmospheric boundary layer. In urban areas, not only the energy balance and the turbulence change, but also the solar radiation storage (short waves) increases because of the materials which are used in the environment (with high thermal capacity). Another alteration is referred to the multiple reflections of longwave radiation that occur within the so-called "Urban Canyons" that contribute to hold energy within the urban canopy, making it difficult for dissipating the upper atmospheric layers. Differently from what happens in the rural areas, the city presents other sources of energy, denominated anthropogenic, that contribute to input more energy in the urban environment, increasing even more the energy gains in the urban canopy. Thus, the causes presented contribute for an increased energy gain and storage in the city, 
bringing, as a consequence, greater heating of the urban environment mainly at night when compared with the rural environment that surrounds it. As a result, aiming to study the energy balance in urban environments, Oke (1987), using the first Law of Thermodynamics (Law of Conservation of Energy) by means of a control volume, computed the gains, losses and the energy storage inside the urban canopy and formulated the equation of Energy Balance that defines the behavior of the urban surface within this control volume according to Equation 1.

$$
\mathrm{Q}^{*}+\mathrm{Q}_{\mathrm{F}}=\mathrm{Q}_{\mathrm{H}}+\mathrm{Q}_{\mathrm{E}}+\Delta \mathrm{Q}_{\mathrm{S}}+\Delta \mathrm{Q}_{\mathrm{A}} \quad \text { Equation } 1
$$

where $\mathrm{Q}^{*}$ is the net all-wave radiation $(\mathrm{K} \downarrow-\mathrm{K} \uparrow+\mathrm{L} \downarrow-\mathrm{L} \uparrow)$, QF the anthropogenic source of heat input in the control volume, QH the turbulent sensible heat flux, QE the turbulent latent heat flux, $\Delta \mathrm{QS}$ the heat storage flux in the urban canopy and $\Delta \mathrm{QA}$ the horizontal advective sensible and latent heat flux conducted toward or away from the control volume (Figure 1), K $\downarrow$ shortwave radiation, $\mathrm{K} \uparrow$ reflected shortwave radiation, $\mathrm{L} \downarrow$ longwave radiation from the sky and $\mathrm{L} \uparrow$ longwave radiation from the surface, all of them considered inside the control volume.

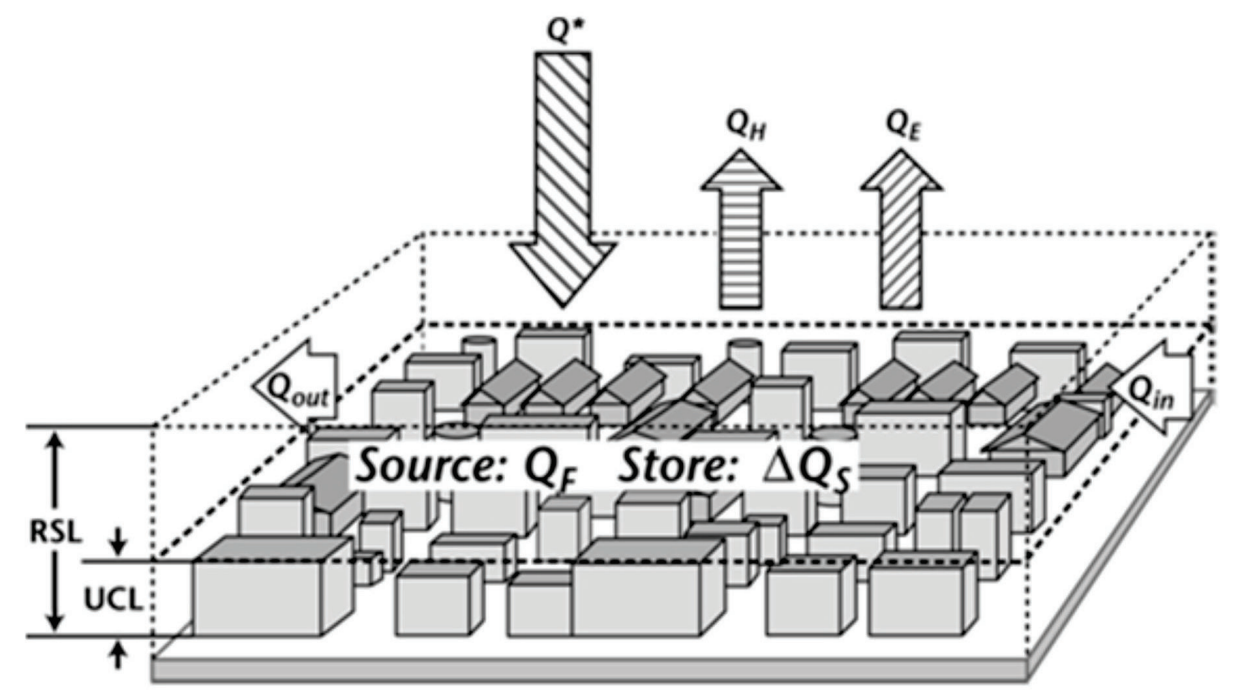

Figure 1 - Schematic illustration of energy balance components in the volume control (urban surface + buildings + air). The surface energy balance per unit of area on the top of the volume control is given by $\mathrm{Q}^{*}+\mathrm{QF}=\mathrm{QH}+\mathrm{QE}+$ $\Delta \mathrm{QS}+\Delta \mathrm{QA}$, where $\Delta \mathrm{QA}=$ Qout $-\mathrm{Qin}$ is the horizontal advective flux that can occur inside the urban canopy, RSL is the roughness sub-layer and UCL is the urban canopy layer. Source: Roberts et al. (2006) adapted Oke (1998).

The urban transformation process in the city of Cuiaba, capital of the State of Mato Grosso, started in the 1930s and it was intensified in the 1960s when it became one of the main supply centers for areas of high agricultural productivity in the Cerrado region and southern Amazon. In 1970, the population of Cuiabá was 88,254 inhabitants and, in 2010, it reached 551,350, increasing more than $624 \%$ (IBGE, 2010). This intense growth and population concentration favored the rapid process of environmental changes, due to the soil surface coverage changes, mainly because of the replacement of great preserved natural areas with built environment and impervious areas. The anthropogenic land occupation was responsible for wide changes in the energy balance causing, among other consequences, influence in the dynamic of air movement, and air temperature increase because of the Urban Heat Island (UHI) phenomenon, affecting on the energy consumption for heating and cooling in the urban buildings (KIM e BAIK, 2004; KOLOKOTRONI et al., 2011).

Studies addressing Energy Balance in urban areas in Brazil and in (sub)tropical climates are still incipient (ROTH, 2007). In a recent work, Ferreira (2010) determined the diurnal and seasonal 
variation of the main components of energy balance in the city of São Paulo during the year of 2004. For the diurnal period, in February, the sensible heat flux, latent heat flux and the heat storage in the urban canopy corresponded to $41 \%, 13 \%$ and $44 \%$ correspondingly to the net energy available, while in August, $46 \%, 14 \%$ e 44\%. The average diurnal Bowen ratio determined for February and August were 3.23 and 3.27, respectively. In Maitelli (2010), it was presented a study of the Energy Balance for the city of Cuiaba, Mato Grosso, in the period of August and September of 1993. During the observations, the average Bowen Ratio observed was 1.02, with values reaching picks up to 5.8, indicating the prevalence of sensible heat fluxes over latent fluxes. During daytime, it was used about $20 \%$ to $52 \%$ of net energy available to heat the air. The sensible heat fluxes when added to the heat stored inside the urban canopy consumed an average of $62 \%$ of net radiation available in the urban system.

\section{OBJECTIVE}

From the circumstances explained above, the aim of this work was to evaluate the seasonal variation of the energy balance in a high density urbanized area in the city of Cuiabá, Mato Grosso State, Brazil, located in tropical climate, during the dry and wet seasons.

\section{MATERIAL AND METHOD}

\section{LOCATION OF THE OBJECT OF STUDY}

The city of Cuiabá is located in the center-southern part of Mato Grosso state, in the western boundary of the domains of the "Cerrado" (Brazilian Savanna) and close to the eastern border of the Pantanal in Mato Grosso (Brazilian Wetlands). Its area is currently 3,538.17 $\mathrm{Km}^{2}, 254.57 \mathrm{Km}^{2}$ corresponding to an urban macrozone area and $3,283.60 \mathrm{Km}^{2}$ to rural area. It is located in the geomorphic province denominated "Baixada Cuiabana". The geographical coordinates are 15'10' a $15^{\circ} 50^{\prime} \mathrm{S}$ and $54^{\circ} 50^{\prime}$ to $58^{\circ} 10^{\prime} \mathrm{W}$. Altitudes vary from 146 meters to 259 meters (IPDU, 2007). The vegetation cover is constituted by remaining of cerrado (Brazilian savanna), cerradão (xeromorphic forest), riparian forest adjacent to the rivers mainly in Cuiabá and exotic vegetation.

The predominant climate in the region is the tropical wet and dry (Köppen climate classification AW), being its main characteristic the constant high temperatures, registering an annual average around $25^{\circ}$ to $26^{\circ} \mathrm{C}$, with two well defined seasons: dry (fall-winter) and wet (spring-summer). Total annual precipitation varies from 1250 to $1500 \mathrm{~mm}$ (CAMPELO JUNIOR et al, 1991).

As a consequence of the population growth occurred in the last decades, new suburbs arose in the city, while the existing ones, mainly in the central areas of the city, suffered densification and verticalization. Therefore, aiming to evaluate the energy flux behavior in areas that suffered intense urbanization, Site 1 was selected located in the Eastern region of the city in the district called "Areão", distant approximately $1.45 \mathrm{Km}$ from downtown, $197 \mathrm{~m}$ above sea level. This site is located inside a state public school, constituted by a central courtyard and linear blocks symmetrically distributed (Figure 3). This district is classified as mixed uses, presenting commercial, institutional and residential building. According to scheme of Urban Climate Zones, it is classified as $U C Z=3$, with highly developed, medium density urban (OKE, 2006).

Based on the fact that the circle of influence on a screen-level temperature or humidity sensor is thought to have a radius of about 500m typically (OKE, 2006), land use and land occupation for the urban site was characterized in terms of fractions of areas into five categories: surface of vegetation (trees, grass, bushes, etc.), pervious surface (bare and partially bare soil), impervious surface (concrete, asphalt, crushed stone, car parking, streets, sidewalks except buildings) and tridimensional surface area of buildings, subdivide in roof area and wall area (Figure 2). Thus, the total area of the active surfaces (fS), i.e, in contact with the atmosphere, was defined as: 


$$
\mathrm{f}_{\mathrm{S}}=\mathrm{f}_{\mathrm{V}}+\mathrm{f}_{\mathrm{I}}+\mathrm{f}_{\mathrm{P}}+\mathrm{f}_{\mathrm{R}}+\mathrm{f}_{\mathrm{C}} \quad \text { Equation } 2
$$

Where $\mathrm{fV}$ is the fraction area of vegetation surface, $\mathrm{fI}$ is the fraction area of impervious surface (concrete and asphalt), fP is the fraction area of pervious surface (bare soil and partially covered), $\mathrm{fR}$ is the the fraction area of building's roof and $\mathrm{fC}$ the fraction area of wall (evaluated from the urban canyons). It is possible to obtain the measurement of the tridimensional morphology of the site dividing the total plain fraction surface area (fplain area) by the total of fraction active surfaces area (fS) inside circle of influence for the urban site (Figure 2). The fraction of the surface for each type of category (fi), as well as the tridimensional fractions can be visualized in Table 1 . The vicinity of the Site 1 and its land use e land occupation can be visualized in Figure 2. As it can be observed, when considering the wall surfaces integrating the area in contact with the atmosphere, Site 1 presents $33 \%$ more area when considering only the plain surfaces (the existing building walls inside the urban canyons increase the urban area in contact with the atmosphere).
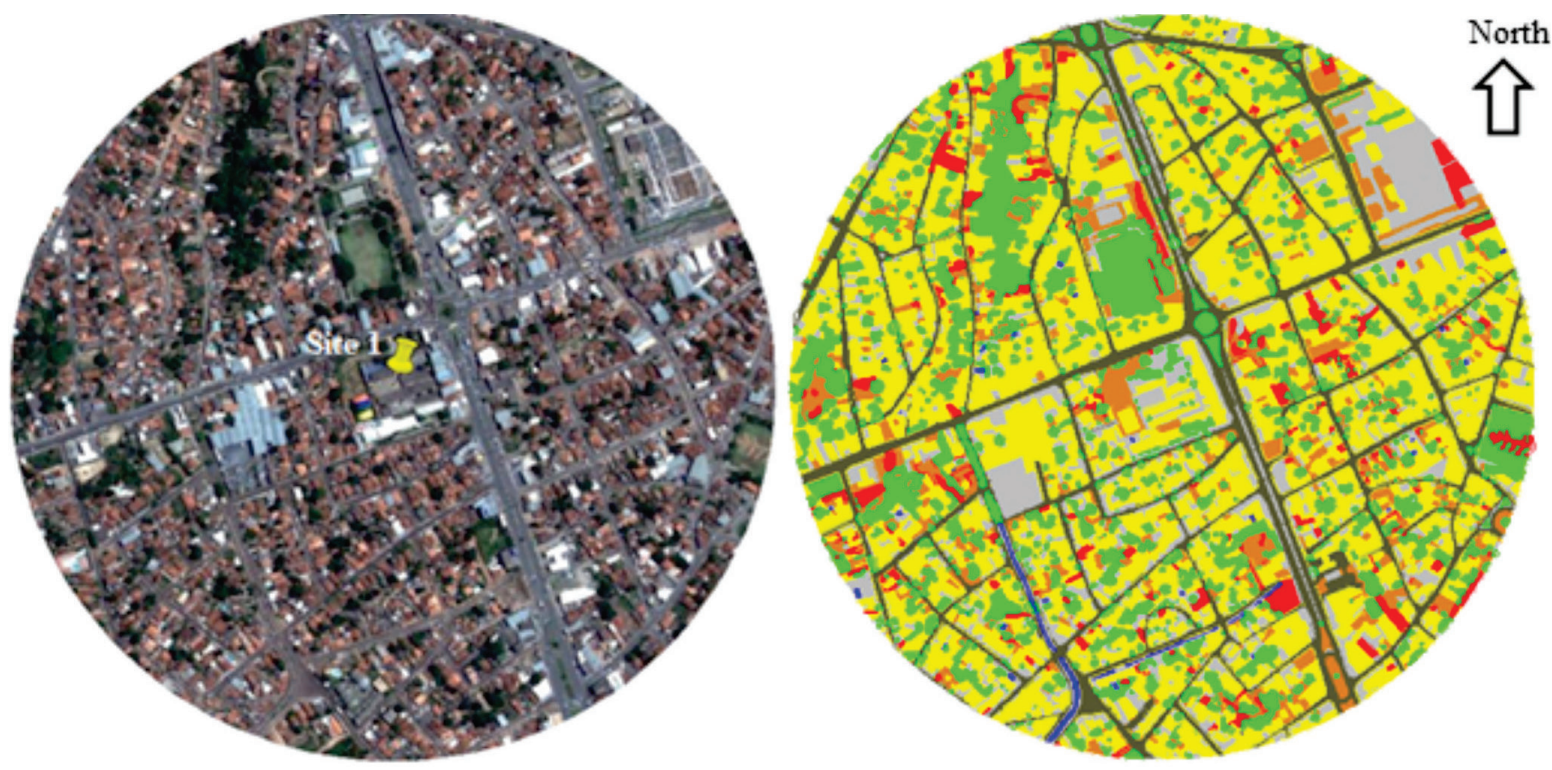

North

Legend

Vegetated area $\square$ Naked soil $=$ Partially naked soil $=$ Building's roof areas $\square$ Asphalt paving

Concrete paving $\square$ Water (river)

Figure 2 - Land use and land occupation inside the circle of influence for site 1 (radius of 500m).

Table 1 - Fraction of area (fi) for each adopted category inside the circle of influence for the Site 1 (radius of $500 \mathrm{~m}$ ).

\begin{tabular}{c|c|c|c|c|c|c}
\hline \multirow{2}{*}{$\begin{array}{c}\text { Land use and } \\
\text { occupation }\end{array}$} & $\begin{array}{c}\text { Impervious area } \\
(\text { asphalt and con- } \\
\text { crete paving) }\left(\mathrm{f}_{\mathrm{I}}\right)\end{array}$ & $\begin{array}{c}\text { Vegetated } \\
\text { area }\left(\mathrm{f}_{\mathrm{V}}\right)\end{array}$ & $\begin{array}{c}\text { Bare and partially } \\
\text { bare soil }\left(\mathrm{f}_{\mathrm{p}}\right)\end{array}$ & $\begin{array}{c}\text { Building's roofs } \\
\text { area }\left(\mathrm{f}_{\mathrm{R}}\right)\end{array}$ & $\begin{array}{c}\text { Urban Canyon area } \\
\left(\text { walls areas) }\left(\mathrm{f}_{\mathrm{C}}\right)\right.\end{array}$ & $\mathrm{f}_{\mathrm{S}} / \mathrm{f}_{\text {plain area }}$ \\
\hline Site 1 & $21.72 \%$ & $11.42 \%$ & $8 \%$ & $33.97 \%$ & $24.88 \%$ & 1.33 \\
\hline
\end{tabular}

\section{MATERIALS}

In order to execute the measurements inside the urban canopy, meteorological instruments were fixed in a pole in the central courtyard of the school (Figure 3): three thermohygrometers, Brand OnsetComp, Model S-THB $(2.5,3.75$ and $7.5 \mathrm{~m})$ to evaluate the temperature and air humidity profile; a net radiometer, Brand Kipp\&Zonen Delft, Inc., Holland, Model NR Lite $2(7.5 \mathrm{~m})$ to evaluate the net radiation; two pyranometers, brand OnsetComp, Model S-LIB (7.5m, one installed upward and the other downward) to evaluate the global incident and reflected solar radiation; a heat flux 
sensor, Brand REBS, Inc., Seattle, Washington, Model HFT-3.1 (5cm under the courtyard concrete slab) to evaluate the heat flux in the concrete; and two cups anemometers, brand OnsetComp, Model S-WSA and S-WCA (5 and 7.5m) to evaluate the wind speed and direction (Figure 3). Data produced by signal and/or electric pulses from the sensors of the meteorological equipment were processed and stored by a Datalogger, brand OnsetComp, Model U30-NRC-VIA-10-S100-000 every 10 seconds and averages at every 5 minutes, and afterwards, the data were processed for intervals of 30 minutes to evaluate energy balance. The experiment was conducted from September (2010) to August (2011), during the dry and wet seasons, respectively.
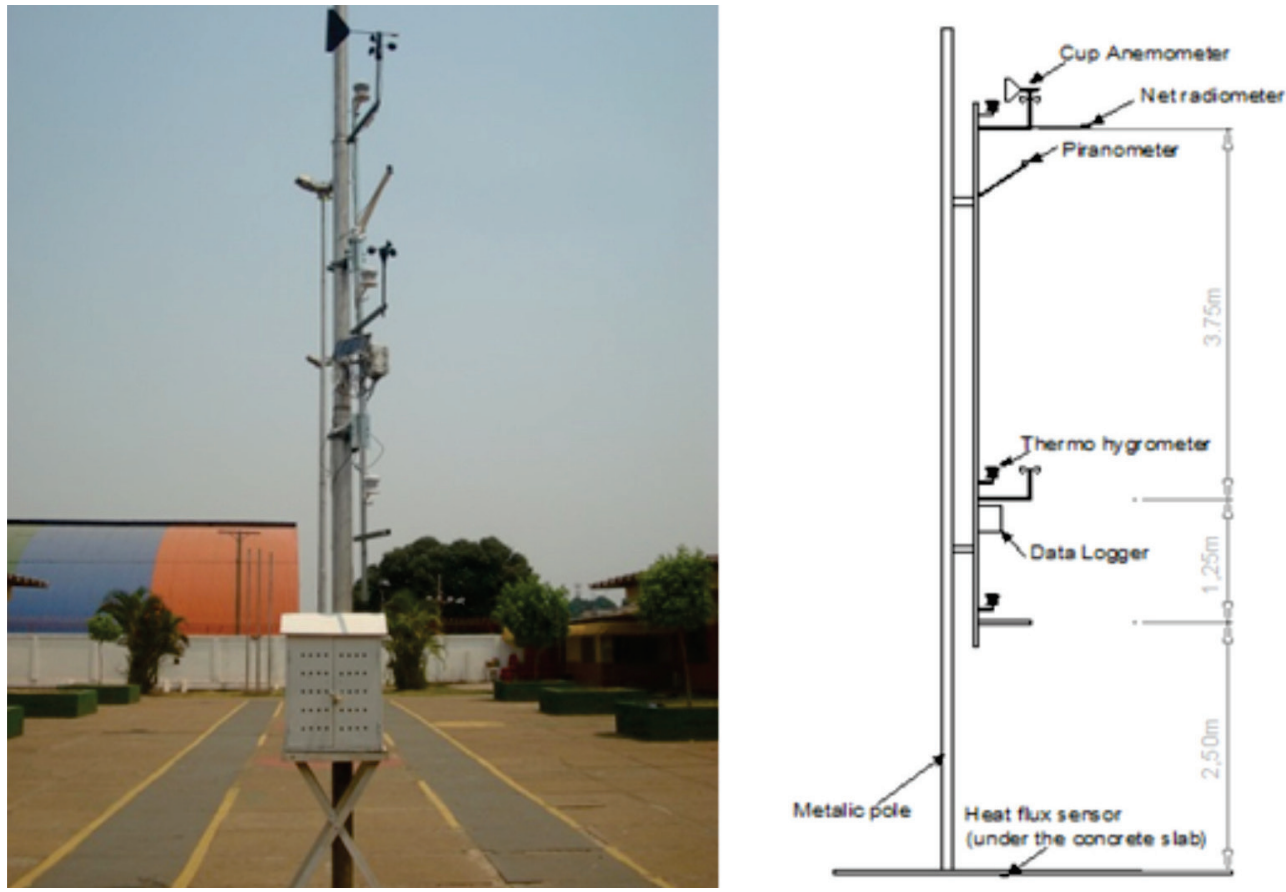

Figure 3 - Meteorological Station: details of the instruments installation.

\section{METHOD}

The Bowen Ratio-Energy Method (BREB) is based on the Law of Conservation of Energy in the system Soil- Air-Atmosphere. The idea used in the method to estimate convective flux is based on the fact that the energy available at the surface $\left(\mathrm{Q}^{*}-\mathrm{QG}\right.$ or $\mathrm{Q}^{*}+\mathrm{QF}-\Delta \mathrm{QS}$, for urban areas) can be distributed to sensible and latent heat fluxes by the ratio between these fluxes $(\beta=Q H / Q E)$. The Monin-Obukhov similarity theory stablishes that $\mathrm{KH} / \mathrm{KE}=\phi \mathrm{H} / \phi \mathrm{E}$, where $\phi \mathrm{H}$ and $\phi$ E represent the universal functions of similarity for the temperature and specific air humidity profiles within the ABL (atmospheric boundary layer). Experimentally, it has been demonstrated that $\phi \mathrm{H}$ is equal to $\phi \mathrm{E}$ in the atmospheric conditions regimes, which suggests it is possible to state that $\mathrm{KH}$ and $\mathrm{KE}$ are similar (FOKEN, 2006). Assuming this hypothesis, it is possible to determine the ratio between the sensible and latent heat fluxes by the Equation 3:

$$
\beta=\frac{\mathrm{Q}_{\mathrm{H}}}{\mathrm{Q}_{\mathrm{E}}}=\frac{\mathrm{K}_{\mathrm{H}}}{\mathrm{K}_{\mathrm{E}}} \frac{\mathrm{c}_{\mathrm{p}}}{\lambda} \frac{\Delta \mathrm{T}}{\Delta \mathrm{q}}=\frac{\mathrm{c}_{\mathrm{p}}}{\lambda} \frac{\Delta \mathrm{T}}{\Delta \mathrm{q}}=\gamma \frac{\Delta \mathrm{T}}{\Delta \mathrm{e}}
$$

\section{Equation 3}

where $\Delta \mathrm{T}$ and $\Delta \mathrm{e}$ refer to the difference of the air temperature $\left({ }^{\circ} \mathrm{C}\right)$ and water vapor pressure $(\mathrm{kPa})$ between two vertical measurement levels, $\mathrm{y}=\mathrm{cpp} / \epsilon \mathrm{Lv}$ is the psychrometric constant, $\mathrm{cp}$ is the specific heat at constant pressure (1.00467 J g-1 K-1), " $p$ " is the atmospheric pressure, " $\epsilon$ " is the ratio of molecular weights of water and air $(0,622)$, and $\mathrm{Lv}$ is the latent heat of vaporization and the other terms have already been defined in Equation 1. Therefore, the Bowen ratio method was used 
to estimate the energy balance components in Site 1 by the use of air temperature gradients $(\Delta \mathrm{T})$ and vapor water pressure in the air $(\Delta \mathrm{e})$ related to the elevations described in item 3.2.

Considering the Bowen Ratio (equation 3) and using the Equation (1) that express the energy balance inside the urban environment and neglecting horizontal advection, latent and sensible heat fluxes were calculated using Equations 4 and 5.

$$
\begin{aligned}
& Q_{E}=\frac{1}{1+\beta}\left[\left(Q^{*}+Q_{F}\right)-\Delta Q_{S}\right] \\
& Q_{H}=\frac{\beta}{1+\beta}\left[\left(Q^{*}+Q_{F}\right)-\Delta Q_{S}\right]
\end{aligned}
$$

\section{Equation 4}

Equation 5

Despite the simplicity of the method, the accuracy of sensible and latent heat fluxes is a function of the Bowen ratio $(\beta)$, which depends on the methodology and equipment used in field measurements. Errors and inconsistent results provided by the Bowen ratio method have been studied by some authors in the last years (KALANDA et al., 1980, PEREZ et al., 1999; FOKEN, 2008, HU et al., 2013). Perez et al. (1999) formulated objective criteria to evaluate when energy fluxes are reliable and accurate, which was revised by $\mathrm{Hu}$ et al. (2013). Those authors executed a physical analysis of the method in order to find some criteria to reject physically inconsistent data, including cases falling out of instrumental precision. The BREB method fails when sensor resolution is inadequate to resolve gradients in $\Delta \mathrm{T}$ and $\Delta \mathrm{e}$, during stable atmospheric conditions, because $\beta$ tends to -1 , such as during the dawn and dusk, and the evapotranspiration tends to infinity, and when atmospheric conditions abruptly change leading to errors in measurement. Thus, to avoid these conditions, it was used a filtered method where physically realistic values of $\beta$ were obtained in an objective and quantitative manner, limiting the potential for bias and error in estimating energy balance terms (PEREZ et al., 1999; HU et al., 2013).

In order to estimate the anthropogenic heat dissipated in the urban canopy, it was used the Inventory Method proposed by Sailor and Lu (2004) in which the heat introduced in the environment by the human activities can be divided in three components that represent the largest sources of heat in the urban environment. By this formulation, the anthropogenic heat was estimated by the Equation 6.

$$
\mathrm{Q}_{\mathrm{F}}=\mathrm{Q}_{\mathrm{FV}}+\mathrm{Q}_{\mathrm{FS}}+\mathrm{Q}_{\mathrm{FM}} \quad \text { Equation } 6
$$

where QFV is the anthropogenic heat flux generated by vehicle sources, QFS generated by stationary sources (electricity consumption and fuel by households, industry and commercial establishments) and QFM generated by human and/or animal metabolism.

The energy stored in the urban canopy $(\Delta \mathrm{Qs})$ was evaluated by Objective Hysteresis Model (OHM) proposed by Grimmond et al. (1991) in which it is possible to describe the non-linear relationship (hysteresis) between radiative forces and the energy stored inside the urban canopy using the Equation 7.

$$
\Delta Q_{s}=\sum_{1}^{n}\left(f_{i} a_{1 i}\right) Q^{*}+\sum_{1}^{n}\left(f_{i} a_{2 i}\right) \frac{\partial Q^{*}}{\partial t}+\sum_{1}^{n}\left(f_{i} a_{3 i}\right)
$$

\section{Equation 7}

where $\Delta \mathrm{QS}$ is the heat flux stored inside the urban canopy; $\mathrm{Q}^{*}$ is the urban net radiation in the studied area, ${ }^{\partial} \mathrm{Q} * / \partial$ t is the time derivative of net radiation, approximated as $0.5(\mathrm{Q} * \mathrm{t}+1-\mathrm{Q} * \mathrm{t}-1)$ with $\mathrm{t}=1 \mathrm{~h}$; a1 $\mathrm{i}$, a2 $\mathrm{i}$ and a3i are empirical coefficients for each type of "i" surface inside the vicinity 
of site 1 (asphalt, concrete, walls, roofs, vegetation, exposed soil) empirically derived from studies relating $\Delta \mathrm{QS}$ to $\mathrm{Q}^{*}$ over specific urban surface types; $\mathrm{fi}$ is the fraction of each surface $\mathrm{i}$ inside the surface area, evaluated in 3.1 (Table 1). In order to apply the scheme proposed by Grimmond et al. (1991), it was necessary to value the net radiation on the site, to execute an inventory of the surface characteristics of the surrounding area (type of existing materials, buildings heights and areas, buildings morphology, fractions of impervious areas, areas with vegetation and urban canyons) as conducted in the item 3.1 and presented in Table 1. The surface fractions attributes (fi) are commonly evaluated by site aerial images, as well as by field surveys (Figure 2). The regression coefficients a1, a 2 and a3, correspond to the response of the hysteresis model for each type of surface existing within the urban environment. Thus, to apply the scheme to the Cuiabá site, the corresponding ali, a2 $\mathrm{i}$ e a3i coefficients were derived utilizing data from site 1 (fluximeter inside the concrete slab), from Miranda Farm site (for soil) and from Sinop Forest Site (for vegetation). For Building roofs, urban canyons and asphalt paving, it was utilized data compiled by Meyn e Oke (2009), Yoshida et al. (1991) and Anandakumar (1999). Table 2 presents only average annual coefficients, but it was utilized average moth coefficients to model the $\Delta \mathrm{QS}$ inside the Site 1.

Table 2 - Average annual coefficients adopted for OHM Model proposed by Grimmond et al. (1991) to estimate the heat flux stored inside urban canopy (Site 1).

\begin{tabular}{|c|c|c|c|c|}
\hline \multirow{2}{*}{$\begin{array}{c}\text { Surface material charac- } \\
\text { teristics }\end{array}$} & \multirow[t]{2}{*}{ Location/Author Data } & \multicolumn{3}{|c|}{ Average annual values } \\
\hline & & $\mathrm{a}_{1}$ (adimensional) & $\mathrm{a}_{2}(\mathrm{~h})$ & $\mathrm{a}_{3}\left(\mathrm{Wm}^{-2}\right)$ \\
\hline Vegetation area & Sinop Forest Data $^{1}$ & 0.03 & -0.03 & -3.30 \\
\hline $\begin{array}{l}\text { bare soil/ partial covered soil } \\
\text { (pasture and grass) }\end{array}$ & Miranda Farm site ${ }^{2}$ & 0.26 & -0.07 & -22.75 \\
\hline Asphalt & Anandakumar (1999) ${ }^{3}$ & 0.84 & -0.83 & -19.29 \\
\hline Concrete & Urban Site ${ }^{4}$ & 0.21 & -0.43 & -13.90 \\
\hline $\begin{array}{l}\text { Building roof cover } \\
\text { (ceramic roof tiles) }\end{array}$ & Meyn e Oke (2009) & 0.07 & 0.26 & -6.0 \\
\hline Urban canyons & Yoshida et al. (1991) & 0.52 & 0.03 & -34.0 \\
\hline
\end{tabular}

(1) Coefficients determined for Sinop forest located in the Amazon-Cerrado transition zone; (2) The regional soil type at Miranda Farm site is rocky dystrophic red-yellow Latosol, also known as a Plinthosol Coefficients were obtained for the period from September 2010 to August 2011 in this rural site located near the city of Cuiabá - MT; (3) It was utilized average negative values of $a_{2}$ e $a_{3 ;}$ (4) The $a_{1}$. $a_{2}$ e $a_{3}$ coefficients were derived by a fluximeter installed under the concrete slab in the Site 1

The results found in this research were compared to those obtained in the same region by Biudes et al. (2009). It was also utilized the research of Ferreira (2010) and Maitelli (2010) because they were the only two researches that conducted urban energy balances inside the urban area at Brazil. Special attention was given to the research conducted in the city of Miami (Florida, USA) (NEWTON et al., 2007) because of its similarity in terms of climate (also classified as Köppen AW) and population to the city of Cuiabá. Results from energy balance of temperate climate countries like those obtained by Grimmond and Oke (2002) (American sites) and Offerle et al. (2006) (European sites) were utilized to contrast the energy balance in the region researched.

\section{ANALYSIS OF RESULTS}

\section{NET RADIATION BALANCE (Q*)}

The average monthly hourly variation of net radiation $\left(\mathrm{Q}^{*}\right)$ and the solar radiation $(\mathrm{Rg})$ can be observed in Figure 4 for dry and wet period respectively. In average, the maximum diurnal values of $\mathrm{Q}^{*}$ in dry season occurred at 12:00 LT, reaching values of 520.9 Wm-2 while in wet season, 
at 11:30 LT with 510.2 Wm-2. The average nocturnal values were $-83.0 \mathrm{Wm}-2$ and $-71.3 \mathrm{Wm}-2$, at 18:00 and 19:00 LT, in dry and wet season, respectively. The maximum diurnal average values of solar radiation $(\mathrm{Rg})$ were observed at 12:00 LT in dry season, reaching values of $694.5 \mathrm{Wm}-2$, while in wet season, at 11:00 LT with $663.7 \mathrm{Wm}-2$. Thus, $\mathrm{Q}^{*}$ and $\mathrm{Rg}$ were in phase in dry season and delayed for half an hour in wet season.

In the energy balance estimated by Ferreira (2010) for the City of São Paulo, the author found maximum average diurnal values of Q* equals to 452 Wm-2 in August and 520 Wm-2 in February, both at $13 \mathrm{~h}$, representative periods of dry and wet seasons, respectively. In the nocturnal period, the minimum average value was -72 Wm-2 at 19:00 LT in August and -41 Wm-2 at 20:00 LT in February. In a rural site located near the city of Cuiabá, Biudes et al. (2009) found maximum average diurnal values for $\mathrm{Q}^{*}$ around $575 \mathrm{Wm}-2$ and $586 \mathrm{Wm}-2$ in dry and wet season, respectively. The nocturnal fluxes were not provided by the author. Maitelli (2010) estimated the energy fluxes inside urban canopy of Cuiabá City in the end of dry season and beginning of the wet season. Results indicated that $\mathrm{Q}^{*}$ reached the maximum value of $510.6 \mathrm{Wm}-2$ in diurnal period and $-55 \mathrm{Wm}-2$ during the first hours of nocturnal period. In the city of Miami (NEWTON et al., 2007), Q* reached maximum diurnal value of approximately $570 \mathrm{Wm}-2$ while during nighttime, values remained almost constant around $-50 \mathrm{Wm}-2$. Based on these results, we can infer that diurnal $\mathrm{Q}^{*}$ values are similar to those observed in the region and in other localities, like São Paulo and Miami. On the other hand, the nocturnal fluxes were higher than those verified in the 90's for city of Cuiaba and in Miami's City. A possible reason for this behavior can be attributed to the differences in the thermal and physical properties of the surfaces inside the urban canopy and to the complex morphometric configuration of the building (like orientations, density, height etc.).
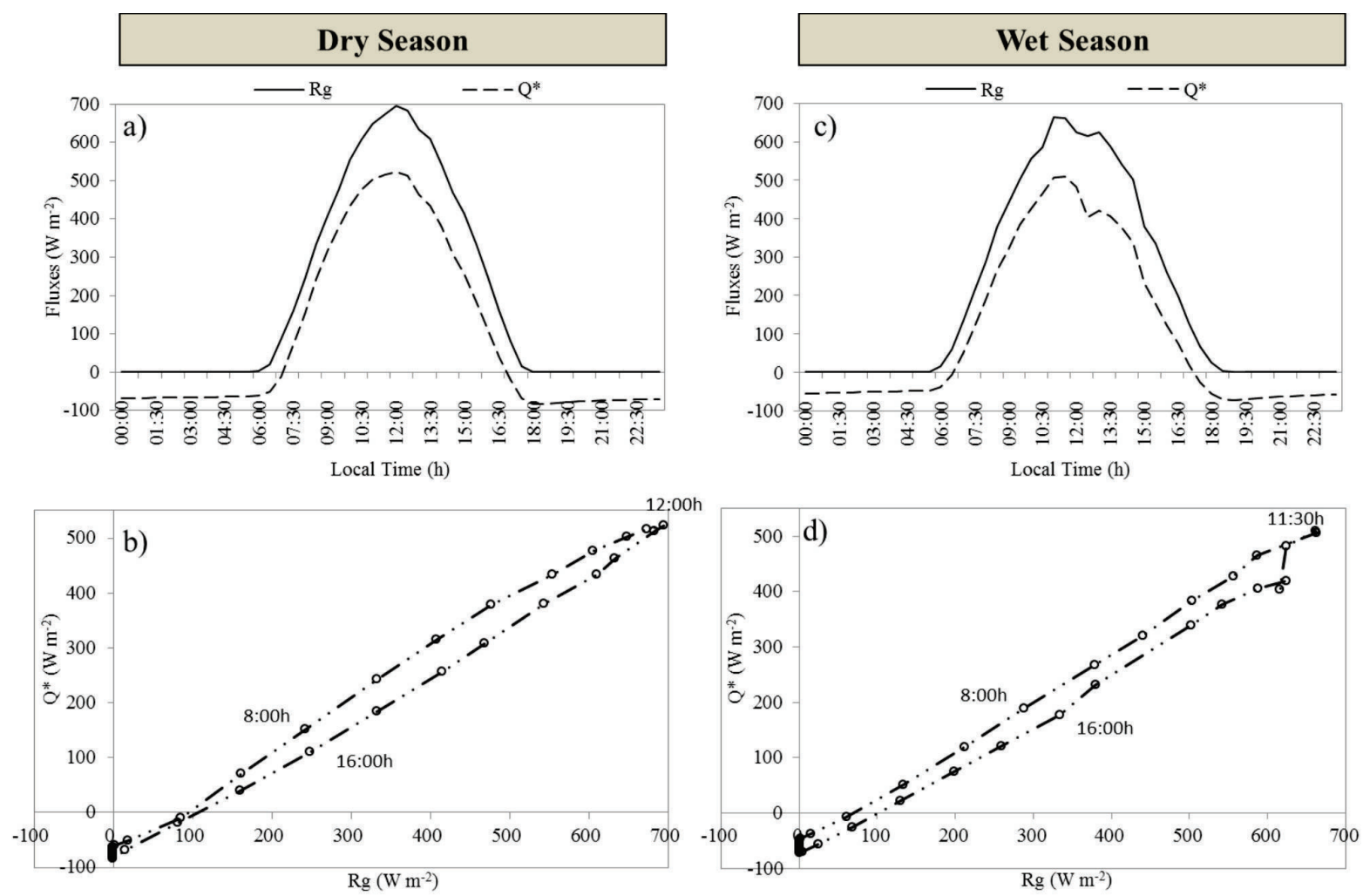

Figure 4 - Average seasonal variation of solar radiation $(\mathrm{Rg}) /$ net radiation $\left(\mathrm{Q}^{*}\right)$ and dispersion diagram for $\mathrm{Rg}$ and $\mathrm{Q}^{*}$ in dry and wet seasons.

The mean annual average ratio of $\mathrm{Q} * / \mathrm{Rg}$ corresponded to approximately $61.6 \%$, while in dry and wet seasons the observed relations were $60.2 \%$ and $63.1 \%$, respectively. These values are below to those verified by Biudes et al. (2009) at rural site in which was found mean annual average ratio 
equal to $80.5 \%$ and for dry and wet season, $69.6 \%$ and $91.4 \%$, respectively. In the energy balance quantified by Maitelli (2010), the $\mathrm{Q}^{*} / \mathrm{Rg}$ ratio from August to September (61.9\%) is quite similar to that observed in the Cuiabá City. For São Paulo and Miami city, authors did not presented the solar radiation in their researches, not allowing comparisons. The results found in this research are close to that registered by Maitelli (2010) but differ considerably from those obtained by Biudes et al. (2009), a rural area near Cuiabá City where soil is covered by pasture and grass vegetation. The differences in the radiation energy balance between the urban and rural surfaces can be attributed to the thermal and spectral characteristics which are influenced by surface albedo, canyon radiative geometric and the moisture state of the ground during the seasons in the region (OKE et al., 1991; CHRISTEN and VOGT, 2004; FERREIRA, 2010).

\section{ANTHROPOGENIC HEAT (QF)}

By analyzing the average daily variation curves of QF during dry and wet seasons (Figure 5), it is possible to verify that anthropogenic heat fluxes presented three periods of maximum dissipation inside the urban canopy: first in the beginning of the morning, from 7:00 to 8:00 LT ( 10 Wm-2), the second at noon, from 11:00 to 12:00 LT $(\sim 10.3 \mathrm{Wm}-2)$ and the third, in the end of the afternoon, from 17:00 to 18:00 LT ( $\sim 9.3 \mathrm{Wm}-2)$. These behavior is similarly to that observed in the city of São Paulo with peaks in the beginning of the morning $(\sim 19.1 \mathrm{Wm}-2)$, another around noon $(\sim 18.6$ $\mathrm{Wm}-2)$ and the last one in the end of the afternoon ( 19.3 Wm-2) (FERREIRA, 2010). Biudes et al. (2009) did not estimate the anthropogenic heat fluxes in rural area because they are usually not considered in energy balance due to the small release of heat inside the rural environment. In turn, in Maitelli (2010) and Newton et al. (2007), they were considered small when compared to the others fluxes, being discarded. On the other hand, Sailor e Hart (2006) estimated anthropogenic heat fluxes dissipated within the urban canopy for various American cities, including the city of Miami, South of Florida. The maximum QF value found for summer was $28.5 \mathrm{Wm}-2$, almost three times higher than the maximum value observed in the city of Cuiabá.

The anthropogenic heat flux dissipated within the urban canopy reflects mainly the pattern of vehicle traffic in the city of Cuiabá, since the vehicle sources (QFV) were the main heat dissipation inside the environment, corresponding to approximately $66.6 \%$ of QF while stationary sources (QFS) and metabolic sources (QFM) corresponded for only 18.2\% and 15.1\%, respectively. In São Paulo, QFV was responsible for approximately 53\% of QF while QFS and QFM were responsible for 38\% and 9\% respectively (FERREIRA, 2010). The lower fraction of stationary sources can be justified by the low fossil fuels consumption (liquefied petroleum gas, fuel oil and natural gas) verified in the city of Cuiabá, compared to the consumption of the city of São Paulo. We can infer that vehicle sources are the main source of heat dissipation inside the urban canopy, especially in cities with smaller population, like Cuiabá.

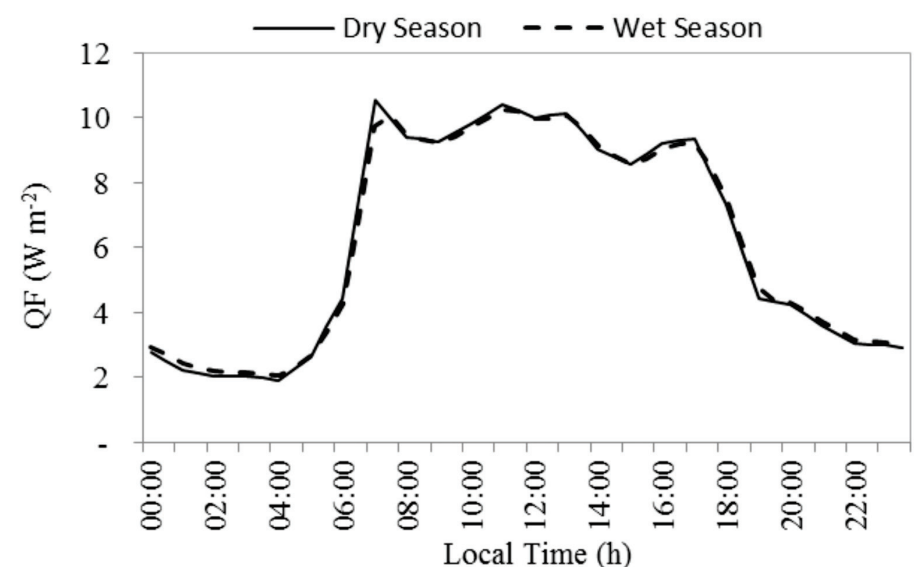

Figure 5-Average daily seasonal variation of anthropogenic heat flux (QF) during dry and wet seasons. 
By the $\mathrm{QF} / \mathrm{Q}^{*}$ ratio, we can infer that anthropogenic heat fluxes presented lower contribution in the urban energy balance during the diurnal period, average of $3.1 \%$, both in dry and wet seasons. However, during the nocturnal period, its contribution raised, reaching values of $30.6 \%$. Based on these results, we can state that in cities located in tropical climates, the anthropogenic heat flux component presents lower contribution in the energy balance. However in those located in temperate climates, due to the elevated consumption of electricity and fossil fuels during winter season for domestic or industrial heating purposes QFS/QF can reaches values up to 70\%, elevating its contribution to the energy balance, mainly during nocturnal period (SAILOR and LU, 2004).

\section{HEAT FLUX STORED WITHIN THE URBAN CANOPY (DQS)}

In average, the maximum diurnal values of $\Delta \mathrm{QS}$ in dry season occurred at 12:30 LT with an intensity of 148.4 Wm-2 while in wet season at 11:30 LT with 134.9 Wm-2. The average nocturnal values were $-42.6 \mathrm{Wm}-2$ and $-38.1 \mathrm{Wm}-2$, at 18:00 and 19:00 LT, in dry and wet season, respectively (Figure 6) and $\Delta \mathrm{QS}$ and $\mathrm{Q}^{*}$ were in phase. When comparing the city to the vicinity's rural site, heat fluxes inside de soil $(\mathrm{G})$ were considerably lower than in Cuiabá's city $(41.4 \mathrm{~W} \mathrm{m-2}$ and $37.6 \mathrm{~W}$ m-2 in dry and wet seasons) (BUIDES et al., 2009) because it doesn't present three-dimensional surfaces (urban canyons) and no impervious surfaces. In turn, soil presents smaller thermal heat capacity and admittance than the traditional artificial materials utilized in the cities, reducing the energy store inside it and cooling down more rapidly at night than urban areas (OKE et al., 1991).

In São Paulo, the intensity in diurnal period reached 273 and $226 \mathrm{Wm}-2$ both at 12:00 LT, and in nocturnal period, -67 e -98Wm-2 at 18:00 and 19:00h, in wet and dry seasons, respectively. Maitelli (2010) estimated $\Delta$ QS by a Net Radiation Parameterization Method and found maximum average diurnal and nocturnal fluxes equal to $100 \mathrm{Wm}-2$ and $-50 \mathrm{Wm}-2$, respectively. In Miami, the average diurnal fluxes were estimated indirectly by Residual Method, reaching values of $200 \mathrm{Wm}-2$ and $-50 \mathrm{Wm}-2$ during daytime and nighttime, respectively. Thus, we conclude that heat fluxes stored inside urban canopy at Cuiabá's City were lower than in other cities but higher than the rural site located near the city. We can affirm the process of urbanization modified the preexisting climate, altering the energy balance in the region. The heat fluxes estimated by Maitelli (2010) were 49\% lower to those observed in this research, probably because of the simplification utilized by the net radiation parametrization method, the differences in the urban morphologic (sky view factor of surface, $\mathrm{H} / \mathrm{W}$ of the canyons etc), thermophysical characteristics between the sites studies and process of urbanization experienced by the city of Cuiabá since 90's.

The diurnal course between $\triangle \mathrm{QS}$ and $\mathrm{Q}^{*}$ didn't show a pronounced temporal hysteresis (Figure 6). The daily peak values were reached almost in the same time of the maximum intensity of Q*. This behavior diverges from that observed in Miami's City (temperate climate) and in The São Paulo's City (subtropical) where it was verified a pronounced temporal hysteresis and peak values were reached $1 \mathrm{~h}$ before the maximum intensity of $\mathrm{Q}^{*}$. Thus, in the Cuiabá urban canopy, the sensible heat conduction process was slower than the ones observed in cities in high altitudes. We speculate the behavior observed by Ferreira (2010) for São Paulo City resulted by the application of empirical coefficients (a1, a2 and a3) determined for temperate cities to the estimation of the heat stored inside the urban canopy $(\Delta \mathrm{QS})$. It is important to mention that the hysteresis is associated to the thermophysical characteristics of the materials found in the environment, such as thermal capacity, diffusivity and effusivity, as well as the amount of moisture inside soil and artificial materials (OKE et al., 1991). 

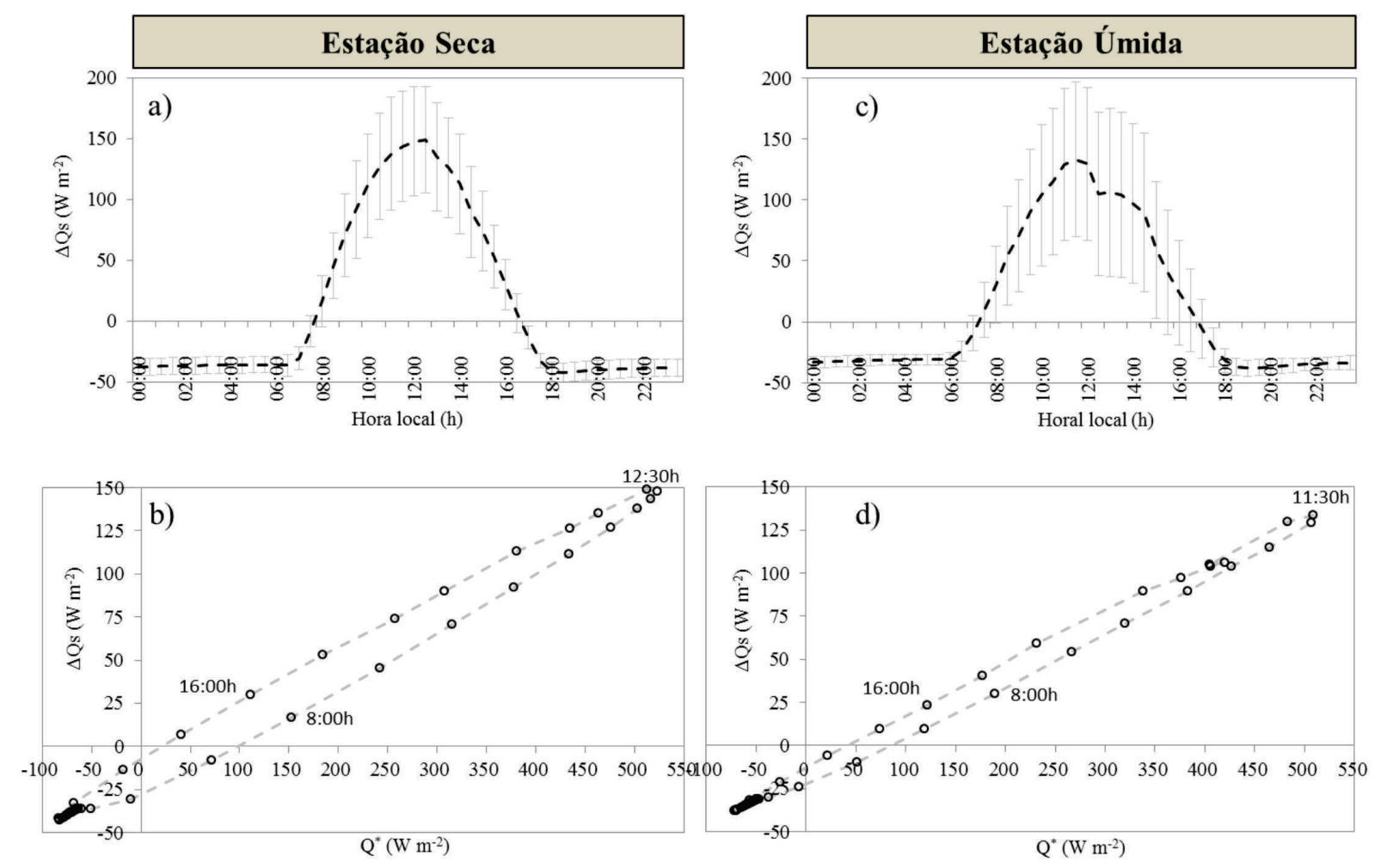

Figure 6 - Average seasonal variation of heat flux $(\Delta \mathrm{QS})$ in the urban canopy and dispersion diagram between $\Delta \mathrm{QS}$ e Q* in dry and wet seasons.

The annual average ratio of $\Delta \mathrm{QS} / \mathrm{Q}^{*}+\mathrm{QF}$ in the diurnal (nocturnal) period corresponded to approximately $24 \%$ (63\%), while in dry and wet seasons, the ratios were $26 \%(60 \%)$ e $24 \%(66 \%)$, respectively (Table 3). The diurnal monthly average ratio of the heat flux stored in São Paulo City corresponded to 24\% of Q* and in Miami City, to 30\%. Maitelli (2010) estimated the heat stored inside the urban canopy by a net radiation parameterization and found ratio of $\Delta \mathrm{QS} / \mathrm{Q}^{*}$ equal to $22 \%$, close in percentage, but lower in intensity than the ones verified in this research.

\section{SENSIBLE HEAT FLUX (QH) AND LATENT (QE)}

The diurnal variations of the hourly average monthly values for the sensible and latent heat fluxes can be visualized in Figures 7 and 8 for the dry and wet seasons, respectively. It was observed that the maximum diurnal (nocturnal) fluxes of QE and QH, in average, occur at 12:00 (18:00 and 19:00 LT) with intensity 134,0 Wm-2 (-29,2 Wm-2) and 243,4 Wm-2 (-8,9 Wm-2) in the dry period and at 10:30 (19:00 LT) and 11:30 (2:00 LT) in the wet season with intensities of 142,1 Wm-2 (-31,1 $\mathrm{Wm}-2)$ and 242,6 Wm-2 (1,82 Wm-2), respectively. When comparing these values with the average maximum diurnal values of net radiation $\left(\mathrm{Q}^{*}\right)$, we noted that the $\mathrm{QE}$ and $\mathrm{QH}$ were in phase with $\mathrm{Q}^{*}$ in the dry season. On the other hand, in the wet season, the maximum value of QE peaked $1 \mathrm{~h}$ before the maximum intensity of $\mathrm{Q}^{*}$, while $\mathrm{QH}$ and $\mathrm{Q}^{*}$ were in phase.

Ferreira (2010) found the maximum value in the diurnal period (nocturnal) of QE and QH equal to $65(1 \mathrm{Wm}-2)$ and $197 \mathrm{Wm}-2(-56 \mathrm{Wm}-2)$ at 14:00 (20:00 LT) in August, 67 (1 Wm-2) and $209 \mathrm{Wm}-2(-19 \mathrm{Wm}-2)$ also at 14:00 (23:00 LT) in February, period that represents dry and wet seasons, respectively. QE and $\mathrm{QH}$ showed hysteresis, delayed $2 \mathrm{~h}$ in relation of $\mathrm{Q}^{*}$, which diverges from those observed in Cuiabá canopy, which are in phase. Despite the differences between Cuiabá and São Paulo, we noted that the sensible heat fluxes were higher than the latent heat fluxes. The temporal hysteresis effects observed on sensible and latent heat fluxes at Sao Paulo and Cuiabá canopies are associated with the speed response of the surface energy input, which varies as function of the latitude, soil characteristics, cloudiness, surface humidity and diurnal variation 


\section{Estação Seca}
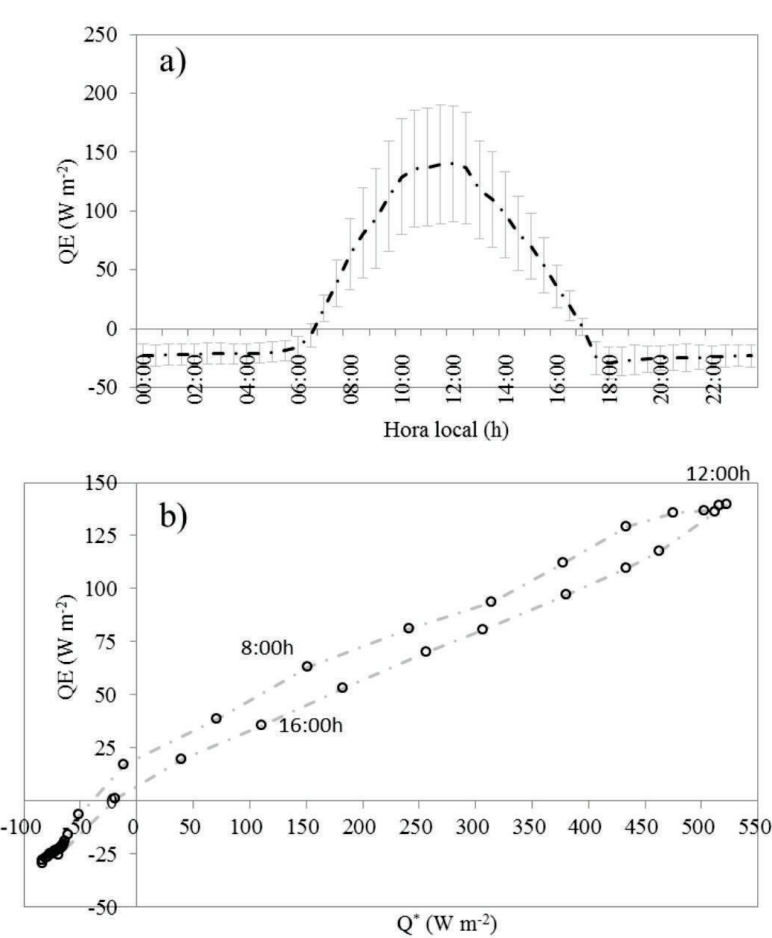

\section{Estação Úmida}

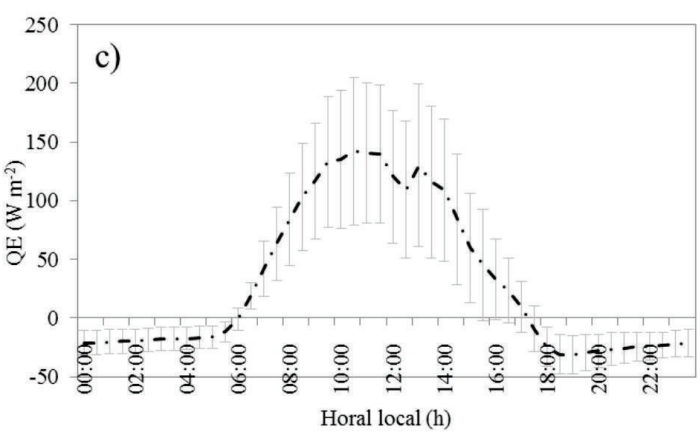

Figure 7 - Average seasonal variation of Latent Heat flux $(\mathrm{QE})$ and dispersion diagram between $\mathrm{QE}$ e $\mathrm{Q} *$ in dry and wet seasons.
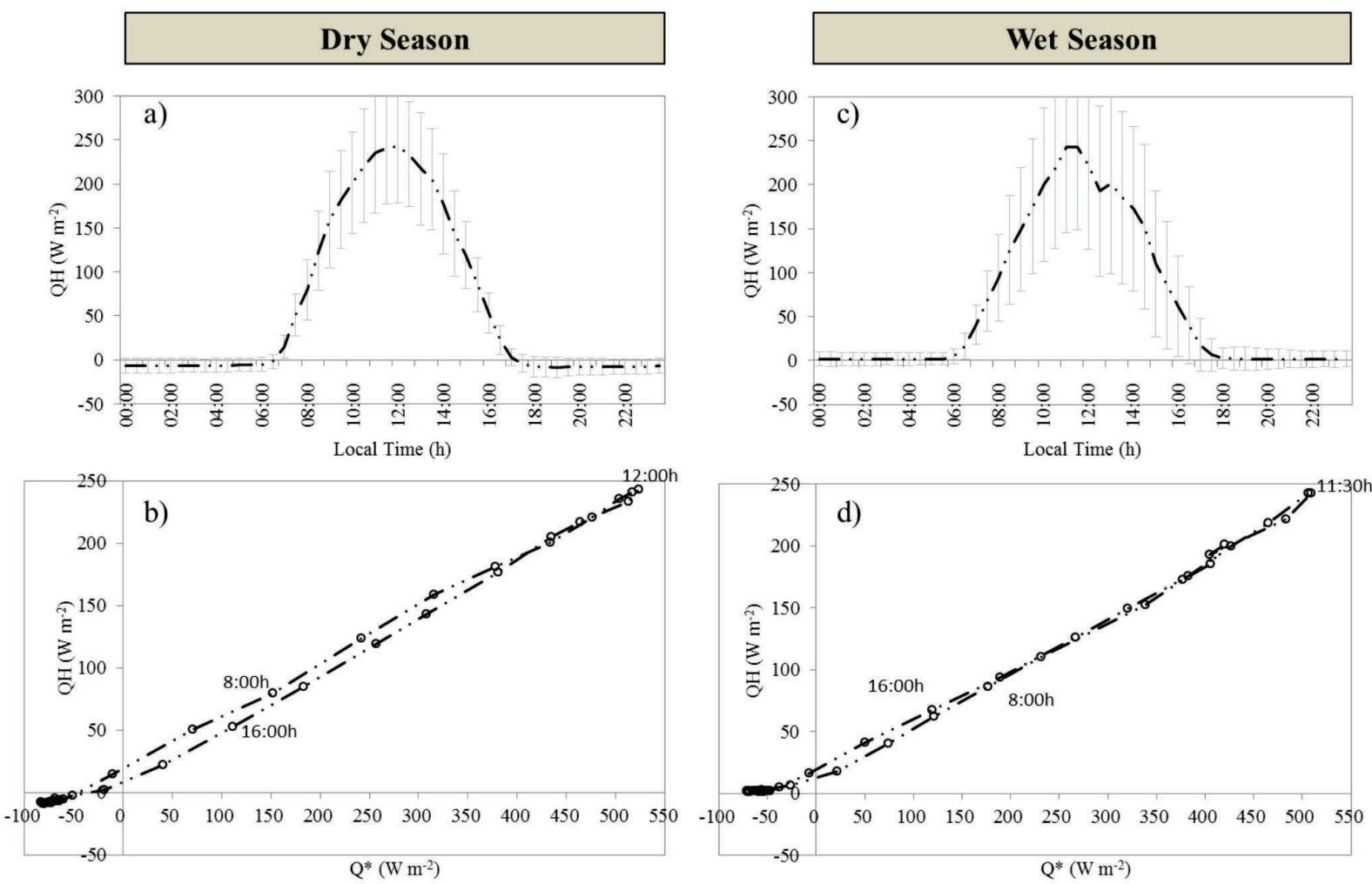

Figure 8 - Average seasonal variation of Sensible Heat flux $(\mathrm{QH})$ and dispersion diagram between $\mathrm{QH}$ e $\mathrm{Q}^{*}$ in dry and wet seasons. 
of atmospheric stability (FERREIRA, 2010). On the other hand, the urbanization is responsible for the elevation of sensible heat fluxes and reduction of latent fluxes inside the urban canopies as will be demonstrated in the next paragraphs. Por outro lado, a urbanização é responsável pela elevação dos fluxos de calor sensível e redução dos fluxos de calor latente no interior dos dosséis urbanos como será demonstrado na sequencia.

In the rural site near Cuiabá City, Biudes at al. (2009) verified that the intensities of QE and QH reached 259.7Wm-2 and 159.3Wm-2 in dry season and $319.7 \mathrm{Wm}-2$ e $234.4 \mathrm{Wm}-2$ in wet season, preponderating QE over QH. The rural area is composed by deforested "Cerrado" and pasture and the elevation of the latent heat flux was expected because presence of no impervious surfaces. In the 90's, Maitelli (2010) verified that the maximum average hourly values of QE and QH were equilibrated, around $200 \mathrm{Wm}-2$. We might expect such reduction in the sensible heat flux since it was observed an intense densification of the urbanization in the Cuiabá central districts, from $\sim 14.3$ to $\sim 34.4 \%$ between the years of 1986 and 2007 (CALLEJAS et al., 2011a). In Miami, QE and QH reached maximum diurnal values of $160 \mathrm{Wm}-2$ and 250 Wm-2 at 13:00 LT, wet period in the region, close to those values verified in the city of Cuiabá.

To demonstrate the influence of urbanization in the sensible and latent heat fluxes, we quantified the plan fraction of vegetated area (fV) and plan fraction of impervious surfaces area (fI) on the Cuiabá site (Table 3). We also presented fV and fI informed by Maitelli (2010), Biudes et al. (2009), Ferreira (2010) and Newton et al. (2007) and the ratios of QE/Q*, QH/QE and QH/(Q*- $\Delta \mathrm{QS}$ ) for $\mathrm{Q}^{*}>0$, aiming to compare them with the results obtained in temperate climate sites located in north American (GRIMMOND and OKE, 2002) and European cities (OFFERLE et al., 2006) (Figure 9).

Table 3 - Plain fraction of vegetated area, plain fraction of impervious area and relations between $\mathrm{QE} / \mathrm{Q}^{*}, \mathrm{QH} /$ QE e QH/(Q*- $\triangle \mathrm{QS}$ ) for Sites 1, Cuiabá (90’s) (MAITELLI,2010), Rural site (BIUDES at al.,2009), São Paulo (FERREIRA, 2010) and Miami (NEWTON et al., 2007) for Q*> 0.

\begin{tabular}{|c|c|c|c|c|c|}
\hline Site & $\begin{array}{l}\text { Fraction of veg- } \\
\text { etated }\left(\mathbf{f}_{v}\right)\end{array}$ & $\begin{array}{c}\text { Fraction of impervious } \\
\text { surface area }\left(\mathbf{f}_{\mathrm{I}}\right)\end{array}$ & $\mathbf{Q}_{\mathbf{E}} / \mathbf{Q}^{*}$ & $\mathbf{Q}_{\mathrm{H}} /\left(\mathbf{Q}^{*}-\Delta \mathbf{Q}_{\mathrm{s}}\right)$ & $\mathbf{Q}_{\mathrm{H}} / \mathbf{Q}_{\mathrm{E}}$ \\
\hline Site 1 & 0.15 & 0.74 & 0.30 & 0.64 & 1.61 \\
\hline $\begin{array}{l}\text { Cuiabá 90’s's (MAITEL- } \\
\text { LI, 2010) }\end{array}$ & 0.20 & 0.80 & 0.38 & 0.40 & 1.02 \\
\hline $\begin{array}{l}\text { Rural site (BIUDES al } \\
\text { al., 2009) }\end{array}$ & 0.95 & 0.05 & 0.57 & 0.30 & 0.62 \\
\hline $\begin{array}{l}\text { São Paulo (FERREIRA, } \\
\text { 2010) }\end{array}$ & 0.05 & 0.75 & 0.15 & 0.93 & 3.27 \\
\hline $\begin{array}{l}\text { Miami-Florida (USA) } \\
\text { (NEWTON et al., 2007) }\end{array}$ & 0.23 & 0.53 & 0.27 & 0.61 & 1.55 \\
\hline
\end{tabular}

We observed that the relation $\mathrm{QE} / \mathrm{Q}^{*}$ in the Cuiabá canopy (Site 1) was above the theoretical curve obtained by Grimmond and Oke (2002) (Figure 9a), indicating that latent fluxes were higher than those measured in the temperate and subtropical climate sites located at North hemisphere. It is also possible to observe that fraction of $\mathrm{QH} /\left(\mathrm{Q}^{*}-\Delta \mathrm{Qs}\right)$ related to the fraction of impervious surface (fI) and followed the theoretical curve established with data from north hemisphere sites (Figure 9b). On the other side, the QH/QE ratios were below the theoretical curve (Figure 9c), which indicates that the sensible heat fluxes measured inside the urban canopy were smaller. We plotted the relations of QE/Q* and QH/QE for Cuiabá in the 90's (MAITELLI, 2010) and we observed similar relations between then and the ones observed at Site 1 , what can be justified by the imprecision quantification of vegetation and impervious area in the vicinity of site since high resolution satellite images were difficult to be found at that time. Since the sensors level installation was not informed in the research, screen-level air temperature or humidity sensor area may have extended to several hundred meters, being influenced by regions of different fractions of vegetated and impervious areas than the ones informed by the author. We also speculated that impervious surface ratios were 
also smaller than the ones indicated in the research, because lower urban densification is expected in the central area of Cuiabá in the 90's as observed by Callejas et al. (2011a), what would justify higher rates of latent heat flux.
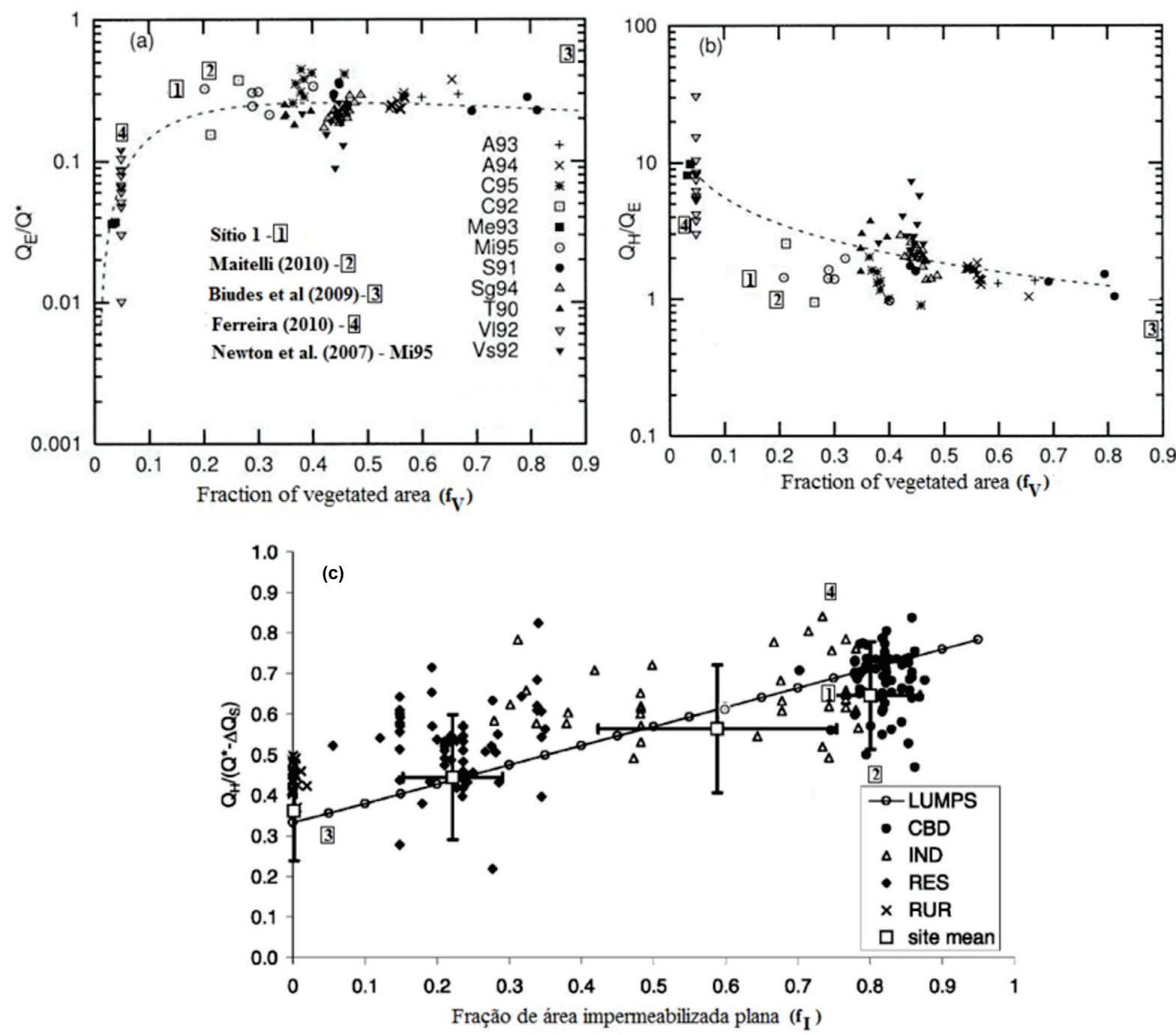

Figure 9 - Relations between (a) QE/Q* and vegetated surface (fV); (b) $\mathrm{QH} /\left(\mathrm{Q}^{*}-\Delta \mathrm{Qs}\right.$ ) and fraction of impervious surface (fI) and (c) QH/ QE and vegetated surface (fV)for sites presented in Table 3 and temperate climate cities. Representative data from 10:00 to 14:00h, local time. Source: (a) and (b) adapted from Grimmond and Oke (2002) and (c) from Offerle et al. (2006).

In the city of São Paulo (FERREIRA, 2010), QE/Q* was smaller than the ones observed in Cuiabá canopy, while QH/QE was above the theoretical curve established for the temperate climate cities. In the rural site (BIUDES at al., 2009), it was observed elevated latent heat fluxes and smaller sensible heat fluxes, which provided QH/QE smaller than 1 (Figure 9c). In the city of Miami-Florida (EUA), it was observed similar ratios to those observed in Cuiabá's city, but smaller because of the lower impervious surface and high vegetated area in the vicinity of Miami's Site.

We observed a great dispersion in the diagram between $\mathrm{QE} / \mathrm{Q}^{*}$ and $\mathrm{QH} /\left(\mathrm{Q}^{*}-\Delta \mathrm{Qs}\right)$, as well as in the $\mathrm{QH} / \mathrm{QE}$ for temperate climates. Thus, it is necessary to perform more experiments in urban tropical climates, especially with different fraction of impervious (fI) and vegetated areas (fV) to verify a tendency observed in this work, i.e, higher latent fluxes and lower sensible fluxes than those observed in temperate climates. 
By analyzing the average daily variation curves of Bowen ratio during dry and wet seasons (Figure 10), it can be observed that the average maximum value of $\beta$ during daytime and nighttime was 1.87 e 0.33 at 13:30 and 4:30 LT, respectively, in dry period. The average daytime $\left(Q^{*}>\right.$ 0 ) and nighttime $\left(Q^{*}<0\right)$ values were 1.66 e 0.30 , indicating that sensible heat fluxes prevailed over the latent heat fluxes during the day, due to low precipitation in period and elevated rates of impervious surfaces inside the Cuiabá urban canopy. ( 74\%) During the wet season, the average maximum value of $\beta$ during daytime and nighttime was 1.98 e -0.70 at 17:00 and 17:30 LT, respectively. Due to the increased water availability in the wet season, the average diurnal $\left(\mathrm{Q}^{*}>0\right)$ and nocturnal $\left(\mathrm{Q}^{*}<0\right)$ values were lower $(1.54 \mathrm{e}-0.08)$ than the ones observed in the dry period, because large amount of energy was utilized to evaporate water (latent heat fluxes), as expected. Due to the small fluxes intensities during nocturnal period, Bowen ratio were erratic and lower than -1, value commonly found in the temperate cities (GRIMMOND and OKE, 2002; LORIDAN AND GRIMMOND et al., 2012).

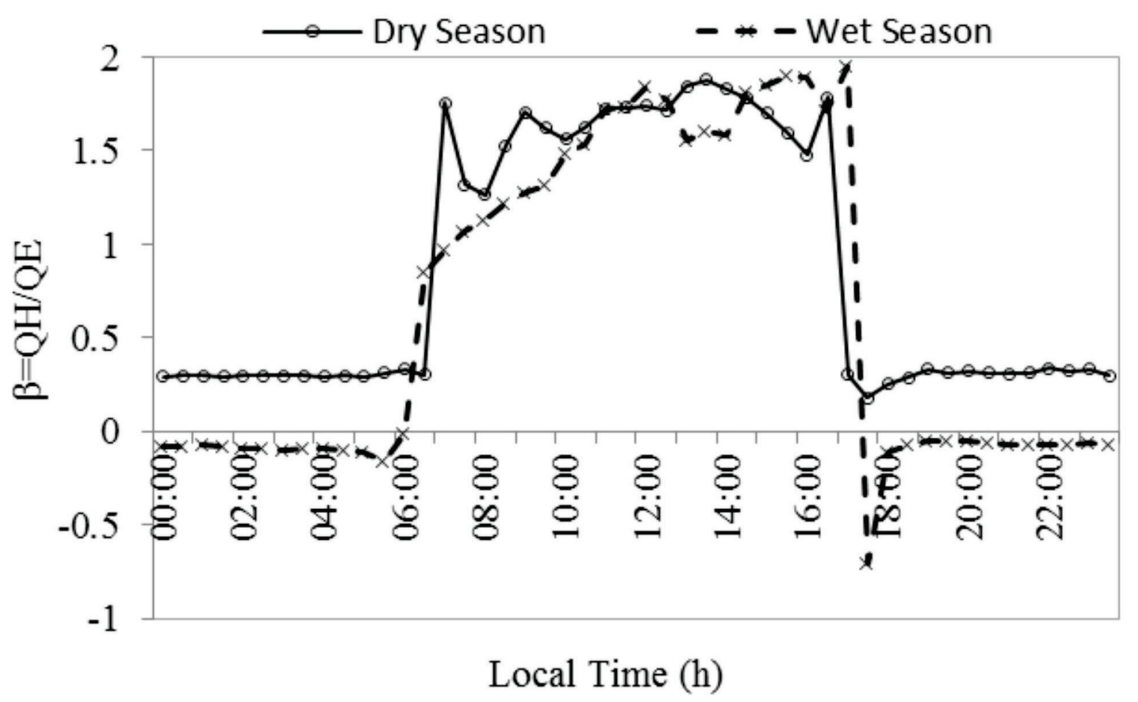

Figure 10 - Average seasonal variation of Bowen ratio in dry and wet seasons.

The seasonal variation of the Bowen ratio in Site 1 indicated minimum average monthly value occurred in the month of February (1.28) and the maximum value in September (2.82). The $\beta$ annual average was 1.61. In dry and wet season, averages values observed were 1.67 and 1.55, respectively, indicating predomination of sensible heat fluxes over latent heat fluxes in Cuiabá urban canopy. The results are consistent with those found in temperate climate cities since vegetation suppression and the sealing of land by impervious surfaces like streets, pavements, car parks and buildings reduces the evapotranspiration inside the urban areas, which corroborates for the predomination of sensible heat fluxes over latent heat fluxes, even in the wet season.

In São Paulo, the $\beta$ average monthly presented a minimum value of 2.92 in September and maximum of 4.29 in June and the annual average was 3.54 (FERREIRA, 2010). These values are much higher than the seasonal value and annual average observed in the Cuiabá urban site. In the rural site, Biudes at al. (2009) verified that the average Bowen ratio in dry and wet seasons were 0.54 and 0.70 , respectively, with an annual average of 0.62 . How rural sites are almost complete pervious, it allows higher evapotranspiration than the urban sites, even in the dry season. For Miami, the average daily intensity of the Bowen ratio was 1.47 in the period of May to July (NEWTON et al., 2007), close to that observed to the Cuiabá City, because similarity in tridimensional morphological characteristics, with $29 \%$ of roofing area, $21 \%$ of urban canyons and 1.33 relation between plain and tridimensional areas (Table 1). For Cuiabá in the 90's, the average Bowen ratios during 
the daytime were 1.02, and during nighttime, lower than the -0.5 (MAITELLI, 2010). The daytime values obtained in this work are inside the observed range for suburban sites ( $\beta=1.2$ to 2 ). Those obtained by Biudes at al. (2009) are next to the range for rural sites $(\beta<0.5)$, while those observed by Ferreira (2010) for urban downtown sites $(\beta>4)$ (LORIDAN and GRIMMOND et al., 2012).

The Bowen ratio behavior inside the Cuiabá's urban canopy indicated that during daytime, fluxes were directed away from the urban canopy (positive). During nighttime, in dry season, the sensible and latent heat fluxes were directed towards to the urban canopy (negative), from upper to the lower urban atmosphere. On the other hand, during the wet season, the sensible heat flux remained positive (upward) and the latent remained negative (downward) inside the urban canopy. The peaks observed in the sunrise and sunset time (Figure 10) occur because of the energy fluxes signal change, as consequences of low vapor pressure deficits/ temperature gradients between the measurements levels (close to the sensor limit accuracy) and with low input/output energy, generating numerical inconsistence in the BREB method (PEREZ et al., 1999; HU et al., 2013).

The positive sensible and latent heat fluxes within the urban canopy occurs due to the release of heat stored $(\Delta \mathrm{QS})$ when there is no radiation input in the urban system $\left(\mathrm{Q}^{*}<0\right)$. This behavior results in the appearance of thermal convection during the nocturnal period because of the regions closer to the surfaces (due to radiative cooling of materials that compose the urban canopy) being warmer and more humid than the upper regions of the urban canopy, inducing turbulence, generating a mixed layer during the nocturnal period. The behavior observed in the lower layers of urban canopy differ from the ones observed in the rural environments, where $\mathrm{QH}$ is directed from the atmosphere to the surface because of the thermal inversion observed in these environments during nocturnal period (BIUDES at al., 2009). It is important to mention that the ascendant fluxes and the changes in the turbulent exchanges observed in the city explain the formation of the phenomenon Urban Heat Island verified between urban and rural environments.

\section{ENERGY BALANCE}

By the analysis of Table 4 and Figure 11, it is possible to verify that anthropogenic heat fluxes were the smaller fluxes in the energy balance during daytime (just 3.1\% in dry and wet seasons). However, during the nocturnal period, because of the suppression of direct solar radiation, its contribution elevated to $30.6 \%$. In general, the net radiation and the anthropogenic heat dissipated within the urban canopy represented annually approximately $97 \%$ and $3 \%$ of the total energy available within the Cuiabá urban canopy. Thus, the contribution of QF in this tropical city were smaller than the ones observed in temperate cities which presents high consumption of electricity and fossil fuels for domestic or industrial heating purposes, especially during nighttime in the winter season.

Heat flux stored within the urban canopy $(\Delta \mathrm{QS})$ is responsible for a large fraction of the energy balance. The average diurnal fractions of $\Delta \mathrm{Qs} /\left(\mathrm{Q}^{*}+\mathrm{QF}\right)$ were $26 \%$ and $24 \%$ in dry and wet seasons, respectively. It was noted that after sunrise there was an intense contribution to thermal conduction and convection and a large amount of energy was stored within the urban canopy and transported to the urban boundary layer (UBL), warming and increasing the turbulence inside the urban canopy in daytime. On the other hand, during the afternoon, it was observed reduction in conduction and convection sensible heat fluxes. The diurnal course between $\Delta \mathrm{QS}$ and $\mathrm{Q}^{*}$ didn't show a pronounced temporal hysteresis. Thus heat stored inside the urban canopy is in phase with $\mathrm{Q}^{*+}+\mathrm{QF}$. During the nocturnal period, the average fraction $\Delta \mathrm{Qs} /\left(\mathrm{Q}^{*}+\mathrm{QF}\right)$ was $60 \%$ and $66 \%$ in dry and wet season. Based on these results we can affirm that the radiation loss during nighttime was supplied almost entirely by removal of heat from storage, inputting energy inside the urban system. The removal of stored sensible heat was partitioned into evaporation $(\mathrm{QE})$ and into nocturnal convection $(\mathrm{QH})$ inside the urban canyons, inducting turbulence and generating a mixed layer during nighttime. These results are consistent with those observed in Miami's City and other North hemisphere Sites (NEWTON et al., 2007; LORIDAN AND GRIMMOND et al., 2012). 
CALLEJAS, I. J. A.; NOGUEIRA, M. C. J. A.; BIUDES, M. S.; DURANTE, L. C.

Table 4 - Daily average values for the energy balance components (Wm-2) and fractions between energy fluxes in diurnal and nocturnal period (dry and wet season).

\begin{tabular}{ccccc}
\hline & \multicolumn{2}{|c}{ Dry season } & \multicolumn{2}{c|}{ Wet season } \\
Period & Diurnal $\left(\mathbf{Q}^{*}>\mathbf{0}\right)$ & Nighttime $\left(\mathbf{Q}^{*}<\mathbf{0}\right)$ & Diurnal $\left(\mathbf{Q}^{*}>\mathbf{0}\right)$ & Nighttime $\left(\mathbf{Q}^{*}<\mathbf{0}\right)$ \\
$\mathrm{Q}^{*}$ & 332 & -66 & 300 & -54 \\
$\mathrm{Q}_{\mathrm{F}}$ & 10 & 4 & 10 & 4 \\
$\Delta \mathrm{Q}_{\mathrm{s}}$ & 87 & -37 & 71 & -33 \\
$\mathrm{Q}_{\mathrm{E}}$ & 94 & -20 & 92 & -19 \\
$\mathrm{Q}_{\mathrm{H}}$ & 158 & -6 & 143 & 3 \\
\hline Fractions & & & & -0.13 \\
$\mathrm{Q}_{\mathrm{H}} / \mathrm{Q}_{\mathrm{E}}$ & 1.67 & 0.28 & 1.55 & 0.66 \\
$\Delta \mathrm{Q}_{\mathrm{s}} /\left(\mathrm{Q}^{*}+\mathrm{Q}_{\mathrm{F}}\right)$ & 0.26 & 0.60 & 0.23 & 0.39 \\
$\mathrm{Q}_{\mathrm{E}} /\left(\mathrm{Q}^{*}+\mathrm{Q}_{\mathrm{F}}\right)$ & 0.28 & 0.33 & 0.31 & -0.05 \\
$\mathrm{Q}_{\mathrm{H}} /\left(\mathrm{Q}^{*}+\mathrm{Q}_{\mathrm{F}}\right)$ & 0.46 & 0.09 & 0.46 & -0.08 \\
$\mathrm{Q}_{\mathrm{H}} / \Delta \mathrm{Q}_{\mathrm{s}}$ & 1.80 & 0.15 & 2.02 & 1.56 \\
$\left(\Delta \mathrm{Q}_{\mathrm{s}}+\mathrm{Q}_{\mathrm{H}}\right) / \mathrm{Q}_{\mathrm{E}}$ & 2.60 & 2.09 & 2.31 & \\
\hline
\end{tabular}

\section{Dry Season}

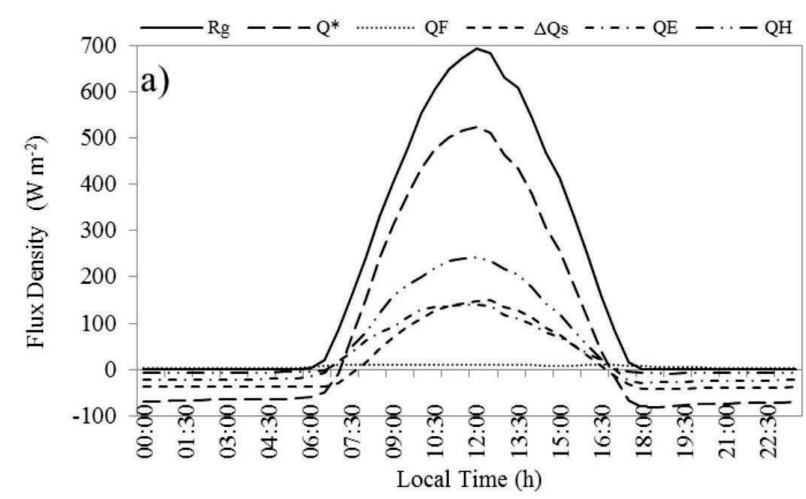

Wet Season

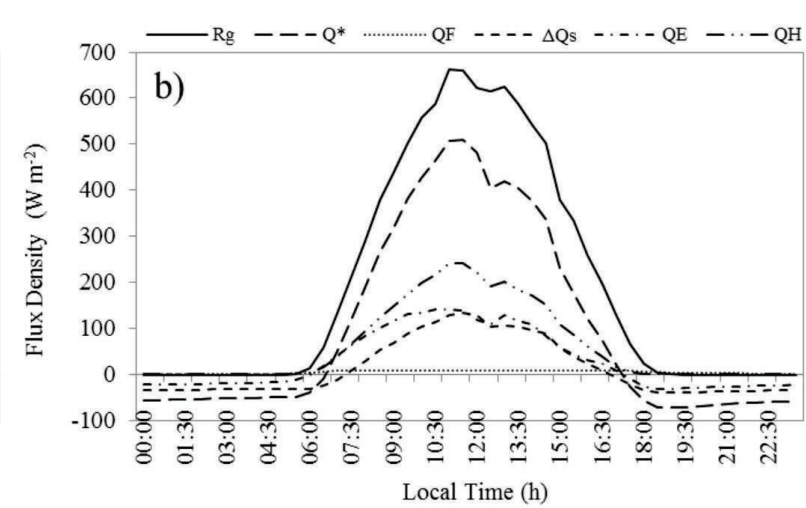

Figure 11 - Daily average monthly values of the energy balance components in dry and wet seasons.

The turbulent latent heat fluxes were systematically inferior to the sensible heat fluxes. The diurnal average fractions of $\mathrm{QE} /\left(\mathrm{Q}^{*}+\mathrm{QF}\right)$ corresponded only to $28 \%$ and $31 \%$ in dry and wet seasons, respectively. It was noted that during morning, the latent heat rates were larger than those observed in the afternoon due to the reduction of the surface humidity as evaporation processes during daytime, mainly during wet season. The diurnal course between $\mathrm{QE}$ and $\mathrm{Q}^{*}$ in dry season were in phase and do not showed hysteresis. On the other hand, in the wet season, the maximum value of QE peak $1 \mathrm{~h}$ before the maximum intensity of $\mathrm{Q}^{*}$. During the night, the average fraction $\mathrm{QE} /\left(\mathrm{Q}^{*}+\mathrm{QF}\right)$ was 33\% and 39\% in dry and the wet season. The latent heat fluxes remained positive inside the urban canyon in the diurnal period and negative, although small, throughout the night. The overall temporal form of $\mathrm{QE} /\left(\mathrm{Q}^{*}+\mathrm{QF}\right)$ and daytime fractions were reasonably similar to those observed in Miami and other North hemisphere cities (NEWTON et al., 2007; LORIDAN AND GRIMMOND et al., 2012).

The turbulent sensible heat fluxes presented the largest contributions inside the energy balance. The average diurnal fractions of $\mathrm{QH} /\left(\mathrm{Q}^{*}+\mathrm{QF}\right)$ in the energy balance corresponded to $46 \%$ in dry and wet seasons, respectively. During the morning, sensible heat fluxes rates were larger than those observed in the afternoon period. QH and $\mathrm{Q}^{*}$ were in phase and do not showed hysteresis in 
the dry and wet season. During the night, the average fraction of $\mathrm{QH} /\left(\mathrm{Q}^{*}+\mathrm{QF}\right)$ reached $9 \%$ and $5 \%$, in dry and wet seasons, respectively. The sensible heat fluxes remained positive inside the urban canyons during daytime and it was related to the diurnal variation in the atmosphere conditions, as instability is increased after sunrise, favoring convection over conduction. During nighttime, fluxes turn negative after sunset (energy is transported away from the urban canopy) and then remain negative until near sunrise in dry season. As mentioned before, the nocturnal urban atmosphere close to the surface remains unstable, an effect mainly driven by the large storage release inside the urban canopy. On the other hand, there were observed small quantities of positive fluxes in wet season. The upward sensible heat flux $(\Delta \mathrm{QS}$ and $\mathrm{QH})$ and the atmosphere instability inside the urban canopy during dry season were responsible for the nocturnal urban heat island in the region (CALLEJAS et al., 2011b). The overall temporal form of QH $/\left(\mathrm{Q}^{*}+\mathrm{QF}\right)$ and daytime fractions were reasonably similar to those observed in Miami, other North American and European cities and near the middle of the range of values observed in urban areas (NEWTON et al., 2007; CHRISTEN and VOGT, 2004).

The fraction of $\mathrm{QH} / \Delta \mathrm{Qs}$ represents the partition of sensible heat flux into convection and conduction (heat stored inside the urban canopy). During daytime, $\mathrm{QH}$ and $\Delta \mathrm{Qs}$ are mainly provide by $Q^{*}$ while in nighttime, due to the suppression of solar radiation, the sensible heat flux (convection - QH and latent - QE), are fed by the dissipation of the sensible heat flux stored within the urban canopy $(\Delta \mathrm{Q} s)$. During the dry and wet seasons, in daytime, the turbulent fluxes of sensible heat were superior to the conductive sensible heat stored inside the urban canopy (fractions of 1.8 and 2.0 , respectively). During nighttime, $\Delta$ Qs was the responsible for providing energy to warm the air and promoting evaporation inside the urban canopy (fractions of 0.15 and -0.08 , respectively). The fraction of $(\Delta \mathrm{Qs}+\mathrm{QH}) / \mathrm{QE}$ indicated that the sensible heat fluxes by conduction and convection are larger (at least 1.5 times) than the latent heat fluxes both in diurnal and nocturnal period, in dry and rainy seasons. By the analysis of these fractions, it is possible to infer that during daytime, most part net radiation is used to warm the urban canopy and stored inside the urban surfaces. In turn, during nighttime, the release of stored heat inside the urban surfaces compensates net radiation losses, warms the urban air, and maintains turbulence and the evaporation throughout nighttime. This behavior was also observed in the suburban sites in the northern hemisphere (GRIMMOND and OKE, 2002; CHRISTEN and VOGT, 2004). The energy balance's fractions evaluated for Site 1 were also similar to those observed for the city of Miami, Florida, USA (Climate Aw) (NEWTON et al., 2007).

\section{FINAL CONSIDERATIONS}

Our motivation in this study was to evaluate the energy fluxes in a dense urbanized area at Cuiabá City, Mato Grosso State, Brazil, located in a hot and dry-wet tropical climate (Köppen climate classification AW). Our intentions were to compare the results with those one obtained for cities located at the north hemisphere, in tropical and temperate climates. Our expectations were to find great differences between the south and north hemisphere sites. However, we observed more similarities than differences. The interaction between properties of surfaces (building, paving, wall etc), soil and atmosphere seems to combine to produce a similar partition on energy balance to those observed in the low and high latitudes located in the north hemisphere.

Cuiabá' city is located under the equator and above tropic of Capricorn, with frequent precipitation and great availability of heat and moisture and also surrounded by wetlands. For these reasons, we expected high taxes of evaporation in the region, but it was not observed. Instead, the high impervious surfaces (74\%) and low vegetated areas (15\%) affected the partition of energy balance inside the Cuiabá's urban canopy, reducing the energy dissipation in form of latent fluxes (QE) when compared to vicinity rural site (reduction of 46 and $24 \%$ in the dry and wet period). We observed, like in Miami and other American/ European sites, that the magnitude and intensity of 
latent fluxes is highly dependent on the total vegetation cover in the vicinity of the site. On the other hand, the heat stored inside the urban canopy was increased by at least three times when compared to rural values. The high three dimensional enlargement proportionated by building surfaces and the physical and thermal properties of the urban fabric, composed basically of artificial materials, allow additional heat storage into buildings. The remaining energy was put into sensible heat flux $(\mathrm{QH})$ which is higher than in the vicinity rural site (increase of 53 and 5\% in the dry and wet period). Thus, a large amount of energy ( $\sim 70 \%$ on average) inside the site was used to warm the air by convection $(\mathrm{QH})$ and was stored inside the urban canopy $(\Delta \mathrm{Qs})$. During nighttime, the release of $\Delta \mathrm{QS}$ and ascendant fluxes of $\mathrm{QH}$ inside the urban canopy were responsible for the nocturnal urban heat island observed in the region. The contribution of anthropogenic heat flux (QF) within the urban canopy were small (3\%) during daytime, but at nighttime, the suppression of direct solar radiation, increased its contribution (33\%), despite the small intensity verified inside the urban canopy in this period.

The fractions of QH, QE and $\triangle \mathrm{QS}$ in the energy balance for Cuiabá's City were similar to those observed in Miami and other residential districts of North American/ European cities. Bowen ratio $(\beta=\mathrm{QH} / \mathrm{QE})$ were 1.67 and 1.55, in dry and wet season respectively, higher than the ones observed in the vicinity rural site and close to the Miami's City (1.47). It is a result of a large amount of waterproofed surface and small amount of area covered by vegetation inside the researched urban site. These values are inside the observed range for suburban sites ( $\beta=1.2$ to 2$)$ and consistent with a medium density urban area $(\mathrm{UCZ}=3)$.

Despite the similarities in the partition of energy balance, we observed that the intensity of fluxes measure inside the Cuiabá's canopy were smaller than those observed in Miami's City, which resulted fractions of $\mathrm{QE} / \mathrm{Q}^{*}$ and $\mathrm{QH} /\left(\mathrm{Q}^{*}-\Delta \mathrm{Qs}\right)$ plotted respectively above and under the theoretical curve obtained by temperate climates. It was also observed that diurnal cycles of heat stored in the urban canopy, sensible and latent heat fluxes differ from those observed in temperate climate cities, since $\Delta \mathrm{Qs}, \mathrm{QH}$, and $\mathrm{Q}^{*}$ were in phase during dry period, observing hysteresis effect only between $\Delta \mathrm{Qs} / \mathrm{QE}$ and $\mathrm{Q}^{*}$. The exception occurred in the wet period, where QE peak $1 \mathrm{~h}$ before $\mathrm{Q}^{*}$, but $\mathrm{QH}$ maintained in phase. For temperate sites, hysteresis effect in $\Delta \mathrm{Q}$ s is pronounced and usually peak 1 to $2 \mathrm{~h}$ before the maximum intensity of $\mathrm{Q}^{*}$. In turn, QH do not presents hysteresis pattern and peak occurs at the same time as net radiation (12:00 LT), while QE is delayed usually to 1 to $2 \mathrm{~h}$ after the maximum intensity of $\mathrm{Q}^{*}$ with hysteresis effect. In the Cuiabá' canopy, we associate this behavior of fluxes remain in phase due to the thermophysical characteristics of the materials found in the urban environment, such as thermal capacity, diffusivity and effusivity, as well as the amount of humidity in present in the soil, indicating that further research in tropical climate cities located under equator must be conducted.

Tropical climate cities usually presents high air temperature throughout the year, with elevated hour of outdoor thermal discomfort and elevated degree-hours for building cooling. Since it was ratified the dependence between sensible/ latent heat fluxes and the fraction of vegetated (fV)/ impervious area (fI) in the urban canopy and in order to balance the fluxes inside the cities, we recommend to review these parameters in the master plan of the cities to avoid excessive urbanization and densification. Following these strategies, we expect to reduce the formation of urban heat islands and its intensification, do not aggravating the external environmental conditions and therefore improving populations' quality of life.

\section{ACKKNOWLEGEMENTS}

The authors acknowledge Mato Grosso Research Foundation (FAPEMAT) for the financial support for this research. 


\section{BIBLIOGRAPHIC REFERENCE}

ANANDAKUMAR, K. A study on the partition of net radiation into heat fluxes on a dry asphalt surface, Atmospheric Environment, v.33, p. 3911-3918, 1999.

BIUDES, M. S.et all. Estimativa do balanço de energia em cambarazal e pastagem no norte do Pantanal pelo método da razão de Bowen. Revista Brasileira de Meteorologia, v. 24, n. 2, p. 135-143, 2009.

CALlEJAS, I. J. A., OLIVEIRA, A. S., SANTOS, F. M. M., DURANTE, L. C.; NOGUEIRA, M. C. J. A., ZEILHOFER, P. Relationship between land use/cover and surface temperatures in the urban agglomeration of Cuiabá/Várzea Grande, central Brazil. Journal of Applied Remote Sensing, v. 5, 053569, 2011 a.

CALlEJAS, I. J. A., OLIVEIRA, A. S., SANTOS, F. M. M., DURANTE, L. C.; NOGUEIRA, M. C. J. A. Estudo comparativo de temperatura e umidade entre meio urbano e rural. In. XI Encontro Nacional de Conforto no Ambiente Construído (ENCAC), Búzios-RJ, Anais. Búzios, 2011 b.

CAMPELO JÚNIOR, J. H.; PRIANTE FILHO, N.; CASEIRO, F. T. Caracterização macroclimática de Cuiabá. III In: Encontro Nacional de Estudos sobre o Meio Ambiente. 1991, Londrina. Anais... 1991. Londrina, 1991. CHRISTEN, A.; VOGT, R. Energy and radiation balance of a central European city. International Journal of Climatology, v.24, p.1395-1421, 2004.

FERREIRA, M. J. Balanço de energia na superfície da cidade de São Paulo. 2010. 183f. Tese. (Doutorado) - Departamento de Ciências Atmosféricas, IAG-USP. São Paulo. SP. Brazil, 2010.

FOKEN, T. 50 years of the Monin-Obukhov similarity theory. Bound. Lay. Met., v.119: p.431-447, 2006. GRIMMOND, C.S.B.; CLEUGH, H.A. and OKE, T.R. An objective urban heat storage model and its comparison with other schemes. Atmospheric Environment, Urban Atmosphere, v.25, n.3, p.311-326, 1991. GRIMMOND, C. S. B.; OKE, T. R. Turbulent Heat Fluxes in Urban Areas: Observations and a Local-Scale Urban Meteorological Parameterization Scheme (LUMPS), J. App. Met., v.41, n.7, p.792-810, 2002.

HU, S., ZHAO, C., LI, J., WANG, F., CHEN, Y. Discussion and reassessment of the method used for accepting or rejecting data observed by a Bowen ratio system. Hydrol. Process., 2013.

IBGE. Instituto Brasileiro de Pesquisas Geográficas. Estimativas Populacionais 2010.

IPDU. Inst. Pesq. e Desenv. Urbano. Perfil Socioeconômico de Cuiabá, V. III, Cuiabá: Central de Texto, 2007. KOLOKOTRONI, M., REN, X.; DAVIES, M.; MAVROGIANNI, A. London's urban heat island: Impact on current and future energy consumption in office buildings. Energy and Buildings, v.47, p. 302-311, 2012. LORIDAN, T.; GRIMMOND, C. S. B. Characterization of Energy Flux Partitioning in Urban Environments: Links with Surface Seasonal Properties. J. App. Met. and Clim., 51(2), p.219-241, 2012.

MAITELLI, G. T. Balanço de Energia Estimado para a Cidade de Cuiabá: Uma Abordagem de Balanço de Energia pelo Método de Bowen. Clima Urbano e Planejamento das Cidades, v.4, n.2, 2010.

MEYN, S., OKE, T. R. Heat Fluxes Through Roofs and Their Relevance to Estimates of Urban Heat Storage. Energy and Building, v.41, p.745-752, 2009.

NEWTON, T. et all. The suburban energy balance in Miami, Florida. Geogr. Ann., v. 89, p.331-347, 2007. MONTEIRO, C. A. F. Teoria e Clima Urbano. São Paulo: IGEO/USP, 1976.

MONTEIRO, C. A. F.; MENDONÇA, F. Clima Urbano. São Paulo: Contexto, 2003.

OKE, T. R; JOHNSON, G. T; STEYN, D. G; WATSON, I. D. Simulation of surface urban heat islands under 'ideal'conditions at night part 2. Boundary-Layer Meteorology, v.56, p.339-358, 1991.

OKE, T. R. Boundary Layer Climates. 2a. Edição, New York: Routledge, 1987. 435p.

OKE, T. R. The Urban Energy Balance. Progress in Physical Geography, v.12, p.471-508, 1988.

OKE, T. R. Initial guide to obtain representative metorological observations at urban site. Word Meteorological Organization. Canada, 2006.

OFFERLE, B. et all. Intraurban Differences of Surface Energy Fluxes in a Central European City. J. Appl. Meteor. Climatol., v.45, p.125-136, 2006.

PEREZ, P.J. et all. Assessment of reliability of Bowen ratio method for partitioning fluxes. Agric. and Forest Meteorology., v.97, n.3, p.141-150, 1999. 
ROBERTS, S. M.; OKE, T. R.; GRIMMOND, C. S. B.; VOOGT, J. A. Comparison of Four Methods to Estimate Urban Heat Storage. J. App. Met. and Clim., v. 45, n.12, p. 1766-1781, 2006.

ROTH, M. Review of urban climate research in (sub)tropical regions. Int. J. Clim. v.27, p. 1859-1873, 2007. SAILOR, D.J.; LU, L.A top-down methodology for developing diurnal and seasonal anthropogenic heating profiles for urban areas. Atmospheric Environment, v.38, 2737-2748, 2004.

SAILOR, D. J, HART, M. An anthropogenic heating database for major U.S. cities. In: Sixth Symposium on the Urban Environment, Boston, Paper 5.6, 2006.

YOSHIDA, A.; TOMINAGA, K.; WATATANI, S. Field measurements on energy balance of an urban canyon in the summer season. Energy Building, v.15-16, p.417-423, 1991. 